\title{
Consequences of dietary energy source and energy level on energy balance, lactogenic hormones, and lactation curve characteristics of cows after a short or omitted dry period
}

\author{
R. J. van Hoeij,, ${ }^{\star 1}$ J. Dijkstra,† R. M. Bruckmaier,ł J. J. Gross,ł T. J. G. M. Lam,§\# G. J. Remmelink,II \\ B. Kemp, ${ }^{*}$ and A. T. M. van Knegsel* \\ *Adaptation Physiology Group, and \\ †Animal Nutrition Group, Department of Animal Sciences, Wageningen University and Research, PO Box 338, $6700 \mathrm{AH}$, Wageningen, \\ the Netherlands \\ †Veterinary Physiology, Vetsuisse Faculty, University of Bern, Bremgartenstrasse 109a, CH-3001 Bern, Switzerland \\ §Department Farm Animal Health, Utrecht University, PO Box 80151, 3508 TD, Utrecht, the Netherlands \\ \#GD Animal Health, PO Box 9, 7400 AA, Deventer, the Netherlands \\ IILivestock Research, Wageningen University and Research, PO Box 338, 6700 AH Wageningen, the Netherlands
}

\begin{abstract}
Omitting the dry period (DP) generally reduces milk production in the subsequent lactation. The aim of this study was to evaluate the effect of dietary energy source - glucogenic $(\mathrm{G})$ or lipogenic (L) - and energy level - standard (std) or low-on milk production; energy balance (EB); lactogenic hormones insulin, insulin-like growth factor 1 (IGF-1), and growth hormone $(\mathrm{GH})$; and lactation curve characteristics between wk 1 and 44 postpartum in cows after a 0 -d or 30-d DP. Cows $(\mathrm{n}=110)$ were assigned randomly to 3 transition treatments: a 30-d DP with a standard energy level required for expected milk yield [30-d DP(std)], a 0-d DP with the same energy level as cows with a $30-d$ DP $[0-d$ DP(std)], and a 0-d DP with a low energy level [0-d $\mathrm{DP}($ low $)]$. In wk 1 to 7 , cows were fed the same basal ration but the level of concentrate increased to $6.7 \mathrm{~kg} / \mathrm{d}$ for cows fed the low energy level and to $8.5 \mathrm{~kg} / \mathrm{d}$ for cows fed the standard energy level in wk 4 . From wk 8 postpartum onward, cows received a $\mathrm{G}$ ration (mainly consisting of corn silage and grass silage) or an L ration (mainly consisting of grass silage and sugar beet pulp) with the same energy level contrast (low or std) as in early lactation. Cows fed the $\mathrm{G}$ ration had greater milk, lactose, and protein yields, lower milk fat percentage, greater dry matter and energy intakes, and greater plasma IGF-1 concentration compared with cows fed the $\mathrm{L}$ ration. Dietary energy source did not affect EB or lactation curve characteristics. In cows with a $0-d$ DP, the reduced energy level decreased energy intake, EB,
\end{abstract}

Received March 10, 2017.

Accepted July 5, 2017.

${ }^{1}$ Corresponding author: renny.vanhoeij@wur.nl and weekly body weight gain, but did not affect milk production or lactation curve characteristics. A 30-d DP resulted in a greater total predicted lactation yield, initial milk yield after calving, peak milk yield, energy intake, energy output in milk, days to conception [only when compared with 0-d DP(low)], plasma GH concentration [only when compared with 0 -d DP(std)], and decreased weekly body weight gain compared with a 0-d DP. A 30-d DP decreased both the increasing and the declining slope parameters of the lactation curve and the relative rate of decline in milk yield (indicating greater lactation persistency) compared with a 0-d DP, and decreased plasma insulin and IGF-1 concentration, and EB. In conclusion, feeding a $\mathrm{G}$ ration after wk 7 in milk improved energy intake and milk production, but did not affect EB compared with an L ration. For cows without a DP, a reduced dietary energy level did not affect milk production and lactation curve characteristics, but did decrease EB and weekly body weight gain. A 30-d DP increased milk yield and lactation persistency, but decreased milk fat and protein content, EB, and plasma insulin and IGF-1, compared with a 0-d DP.

Key words: continuous milking, persistency, body condition, metabolic status

\section{INTRODUCTION}

A conventional dry period (DP) length of 6 to 8 wk has been applied for several decades and maximizes milk production in the subsequent lactation (Grummer and Rastani, 2004). High milk yield in early lactation results in a negative energy balance (EB), with associated metabolic disorders such as ketosis, fatty liver, and impaired fertility (Ingvartsen et al., 2003). Shortening or omitting the DP has been suggested as a management measure to improve $\mathrm{EB}$ and metabolic 
status of dairy cows in early lactation (Annen et al., 2004; Rastani et al., 2005; Schlamberger et al., 2010).

Improvement of the EB after a $0-d$ DP is mainly a result of a reduction in milk production, compared with a 30-d or 60-d DP (Annen et al., 2004; de Feu et al., 2009), and sometimes also due to an improvement of energy intake (Rastani et al., 2005). Postpartum milk yield losses as a result of omitting the DP are partially compensated by additional milk yield in the precalving period (Rastani et al., 2005; van Knegsel et al., 2014). It was hypothesized that a greater persistency of milk yield in the subsequent lactation could also partly compensate for milk losses in early lactation and potentially increase total lactation yield in cows after a short or omitted DP (Grummer and Rastani, 2004). Later, experimental studies reported ambiguous effects of DP length on lactation persistency. Shortening or omitting the DP reduced lactation persistency (Mantovani et al., 2010; persistency expressed as absolute decline in milk yield), increased lactation persistency in primiparous cows (Atashi et al., 2013; persistency calculated from lactation curve characteristics) or did not affect lactation persistency (multiparous cows, Atashi et al., 2013; Chen et al., 2016a; persistency expressed as absolute decline in milk yield). In the latter study, the BCS of cows with a 0-d DP increased in late lactation compared with cows with a 30- or 60-d DP (Chen et al., 2016b).

Lactation persistency can be improved by administration of exogenous growth hormone (GH; Van Amburgh et al., 1997; Bauman, 1999) and is slightly related to the endogenous plasma GH concentration (Sorensen and Knight, 2002). Growth hormone increases nutrient partitioning toward milk (Hart, 1983; Lucy, 2004), and GH release from the pituitary gland is inhibited by IGF-1(Berelowitz et al., 1981; Tannenbaum et al., 1983). Hepatic production of IGF-1 is positively related to plasma glucose and insulin concentration (Butler et al., 2003). Specific dietary measures such as energy level (Kokkonen et al., 2004; Lucy et al., 2009; Grala et al., 2011) and energy source (Gong et al., 2002; van Knegsel et al., 2007a,b) affect lactogenic plasma hormone concentrations such as insulin, IGF-1, and GH, and partitioning of energy toward milk (Mashek et al., 2002). Several studies have evaluated lactation curve characteristics during bST treatments and illustrated how the increasing slope of the lactation curve, peak yield, and lactation persistency were related to plasma IGF-1 and GH concentrations (Van Amburgh et al., 1997; Bilby et al., 2006). Differences in plasma insulin, IGF-1, and GH concentrations due to differences in DP length or dietary energy level or dietary energy source are hypothesized to affect lactation curve characteristics.
Feeding a lipogenic ration may increase lactation persistency (Cannas et al., 2002). Feeding a lipogenic ration resulted in lower plasma glucose (Chen et al., 2016b), insulin (van Knegsel et al., 2007a,b, Chen et al., 2016b), and IGF-1 (Chen et al., 2016b) concentrations in early lactation compared with a more glucogenic ration. Other studies, however, did not find differences in plasma glucose, IGF-1, GH (Garnsworthy et al., 2008, 2009; Chen et al., 2016a), or insulin (Chen et al., 2016a) concentrations after feeding a more lipogenic than glucogenic ration. Differences among studies could be related to the number of cows in the study, the contrast in lipogenic and glucogenic nutrient availability between different rations within a study, or the stage of lactation when rations were fed. In mid and late lactation, a lipogenic ration reduced plasma glucose and insulin concentrations compared with a more glucogenic ration (Voelker and Allen, 2003; Mahjoubi et al., 2009). In light of the correlation between insulin and GH (Hart et al., 1979), we hypothesized that a lower plasma insulin concentration after peak milk yield stimulates plasma GH concentration and lactation persistency.

Feeding an energy level aimed at zero EB to prevent fattening in late lactation may be another measure to stimulate lactation persistency of cows with a short DP or no DP compared with feeding an excess energy level such as in Chen et al. (2016a). It can be hypothesized that limiting intake of $\mathrm{NE}_{\mathrm{L}}$ aiming at zero $\mathrm{EB}$, adjusted for the lower milk yield of cows with a 0-d DP, lowers plasma glucose and insulin concentrations, elevates plasma GH concentration, increases partitioning of energy toward milk yield and lactation persistency, and prevents fattening of cows after a 0-d DP. So far, the effects of DP length on milk yield and EB in the subsequent lactation have been evaluated with a lactation ration containing the same energy level for all cows.

The aim of this study was to evaluate the effect of dietary energy source and of dietary energy level on milk production, EB, lactogenic hormones, and lactation curve characteristics in cows after a $0-\mathrm{d}$ or $30-\mathrm{d}$ DP.

\section{MATERIALS AND METHODS}

\section{Animals and Housing}

The Institutional Animal Care and Use Committee of Wageningen University (Wageningen, the Netherlands) approved the experimental protocol in compliance with the Dutch law on Animal Experimentation (protocol number 2014125). The experiment was conducted at the Dairy Campus research farm (Lelystad, the Nether- 
lands) between January 27, 2014, and May 9, 2016. The research herd was composed of 400 lactating Holstein cows. For this experiment, cows were selected based on (1) being bred with a Holstein sire, (2) expected calving interval $<490 \mathrm{~d}$, (3) daily milk yield $>16 \mathrm{~kg}$ at $90 \mathrm{~d}$ before the expected calving date, and (4) no clinical mastitis and preferably SCC $<250,000$ cells/ $\mathrm{mL}$ at final 2 test-days before the conventional drying off day. Cows pregnant with twins were not included in the experiment. Cows were housed in a freestall with a slatted floor and cubicles. Cows were milked twice daily at approximately 0600 and $1800 \mathrm{~h}$. The drying-off protocol for cows with a 30-d DP consisted of a transition to the dry cow ration at $\mathrm{d} 7$ before drying off and to milking once daily from d 4 before drying off. At drying off, no dry cow antibiotics were used.

\section{Experimental Design}

In total, 130 cows entered the experiment, including 6 cows that entered twice. To obtain a balanced distribution of cows across treatments, cows were blocked according to expected calving date, milk yield in the previous lactation, and parity $(2, \geq 3)$ in the subsequent lactation. Within each group of 6 cows, 4 cows were assigned randomly to a DP length treatment of $0 \mathrm{~d}$ and 2 cows to a DP length treatment of $30 \mathrm{~d}$. Within the group of cows with a 0 -d DP, cows were assigned randomly to either a low level of energy in wk 4 to 44, which is based on the requirement for their expected milk yield (low) or a standard (std) level of energy based on the requirement for the expected milk yield of cows with a 30-d DP. Cows with a 30-d DP were fed a standard level of energy, which is based on the requirement for their expected milk yield. From wk 8 postpartum onward, cows received either a glucogenic $(\mathbf{G})$ or a lipogenic $(\mathbf{L})$ basal ration. This resulted in the following 3 transition treatments, each with 2 different rations: cows with a $30-\mathrm{d}$ DP and a standard dietary energy level [30-d DP(std)] and fed a $\mathrm{G}(\mathrm{n}=19)$ or $\mathrm{L}(\mathrm{n}=21)$ ration, cows with a 0 -d DP with the same standard dietary energy level [0-d DP(std)] as cows with a 30-d DP and fed a $\mathrm{G}(\mathrm{n}=18)$ or $\mathrm{L}(\mathrm{n}=16)$ ration, and cows with a $0-\mathrm{d}$ DP with a low energy level $[\mathbf{0}-\mathbf{d}$ DP(low $)]$ and fed a $\mathrm{G}(\mathrm{n}=16)$ or $\mathrm{L}(\mathrm{n}=20)$ ration. The experimental period of the current study started at calving and lasted until wk 44 postpartum.

\section{Rations}

The ingredient and nutrient composition of the basal rations and of the concentrates are presented in Tables 1 and 2, respectively. The basal (early lactation) ration was fed for 7 wk and was described previously in van Hoeij et al. (2017). In short, all cows were fed the same basal ration for $7 \mathrm{wk}$ postpartum, including $1 \mathrm{~kg} / \mathrm{d}$ of standard concentrate in the milking parlor. All cows received $1 \mathrm{~kg} / \mathrm{d}$ of experimental concentrate from $10 \mathrm{~d}$ before the expected calving date. Experimental concentrate supply increased stepwise by $0.3 \mathrm{~kg} / \mathrm{d}$ from 4 DIM up to an experimental concentrate intake of $8.5 \mathrm{~kg} / \mathrm{d}$ at $28 \mathrm{DIM}$ for cows receiving the ration with the standard energy level [30-d DP(std) and 0-d $\mathrm{DP}(\mathrm{std})]$, or stepwise by $0.3 \mathrm{~kg} / \mathrm{d}$ from 4 DIM up to an experimental concentrate intake of $6.7 \mathrm{~kg} / \mathrm{d}$ at $22 \mathrm{DIM}$ for cows receiving the ration with the low energy level $[0-\mathrm{d} \mathrm{DP}(\mathrm{low})]$. The difference in dietary energy level between the low and standard ration was based on previous research, in which cows with a $0-\mathrm{d}$ DP $[35.4 \mathrm{~kg}$ of fat- and protein-corrected milk (FPCM)/d] produced $12 \%$ less FPCM between 1 and 14 wk in lactation than cows with a $30-\mathrm{d}$ DP (40.4 kg of FPCM/d; van Knegsel et al., 2014). Cows with a 0-d DP were fed the low dietary energy level, which was calculated for the expected milk yield of cows with a 0-d DP, or the standard dietary energy level, which was calculated for the expected milk yield of cows with a 30-d DP. Cows with a 30-d DP were only fed the standard dietary energy level. The experimental concentrate decreased stepwise by $0.5 \mathrm{~kg} /$ wk starting in wk 15 to $0 \mathrm{~kg} / \mathrm{d}$ in wk 31 for cows with a standard dietary energy level. The experimental concentrate decreased stepwise by $0.4 \mathrm{~kg} / \mathrm{wk}$ starting in wk 15 down to $0 \mathrm{~kg} / \mathrm{d}$ in wk 31 for cows with a low dietary energy level. Experimental concentrate was provided individually over 6 periods within $24 \mathrm{~h}$ by a computerized feeder located in the freestall that was available to all cows at all times (Manus VC5, DeLaval, Steenwijk, the Netherlands). From 8 wk postpartum onward, the glucogenic and lipogenic basal ration were supplied. The basal rations were calculated to be isocaloric, within a standard or low energy level. Cows had free access to water and basal ration throughout the experiment.

Rations were mixed once daily at approximately 1000 $\mathrm{h}$ and fed twice daily at 1000 and $1700 \mathrm{~h}$. Dry matter content of basal ration was measured daily. Forage samples were taken weekly and stored at $-20^{\circ} \mathrm{C}$ until analysis. Net energy was calculated using the Dutch NE system for lactation (VEM; Van Es, 1975), and intestinal digestible protein (IDP) and rumen-degradable protein balance (RDPB) were calculated according to the Dutch DVE/OEB system (Tamminga et al., 1994).

\section{Measurements}

Milk Yield and Milk Composition. Milk yield was recorded daily from day of calving until 44 wk postpartum. Milk samples for fat, protein, and lactose 
analysis (ISO 9622, ISO, 2013; Qlip, Zutphen, the Netherlands) were collected 4 times per wk (Tuesday afternoon, Wednesday morning, Wednesday afternoon, and Thursday morning) and were analyzed as a pooled sample of 2 morning and 2 afternoon milkings per cow per week. Fat- and protein-corrected milk was calculated as follows (CVB, 2011):

$$
\begin{aligned}
& \operatorname{FPCM}(\mathrm{kg} / \mathrm{d})=[0.337+0.116 \times \text { fat content }(\%) \\
& +0.06 \times \text { protein content }(\%)] \times \text { milk yield }(\mathrm{kg} / \mathrm{d})
\end{aligned}
$$

Feed Intake, BW, BCS, and Conception. Daily basal ration intake was measured individually using roughage intake control troughs and was averaged per week (Insentec, Marknesse, the Netherlands). The stocking density was 2 cows per trough. Concentrate supply $(\mathrm{kg} / \mathrm{d})$ was recorded by a computerized feeder (Manus VC5, DeLaval). Body weight was recorded daily before each milking and averaged per week; weekly BW gain was calculated. Body condition score was measured using a 1 to 5 scale by the same person every $4 \mathrm{wk}$ (Ferguson et al., 1994). Cows were inseminated after a voluntary waiting period of $50 \mathrm{~d}$ until at least 170 DIM. Artificial insemination took place $12 \mathrm{~h}$ after detection of estrus, which was detected using Lely Qwes-HR Activity Tags (Lely, Maassluis, the Netherlands) mounted on the neck collar.

Pregnancy was checked every $4 \mathrm{wk}$ by a veterinarian for cows inseminated $>30 \mathrm{~d}$ before the pregnancy check.

Blood Collection. Blood was collected weekly from calving until wk 10 postpartum, and every 2 wk between wk 12 and 44 postpartum. Blood samples were collected after the morning milking and between 3 and

Table 1. Ingredient and nutrient composition of the average basal ration fed for $7 \mathrm{wk}$ postpartum (R-7wk), and of the average glucogenic $(\mathrm{G})$ and lipogenic (L) basal rations at standard energy level (std) or reduced

\begin{tabular}{|c|c|c|c|c|c|}
\hline \multirow[b]{2}{*}{ Item } & \multicolumn{5}{|c|}{ Ration } \\
\hline & R-7wk & G-low & G-std & L-low & L-std \\
\hline \multicolumn{6}{|l|}{ Ingredient ( $\mathrm{g} / \mathrm{kg}$ of $\mathrm{DM})$} \\
\hline Grass silage 1 & 437 & 162 & 175 & 571 & 619 \\
\hline Corn silage $^{2}$ & 338 & 519 & 616 & 0 & 0 \\
\hline Sugar beet pulp & 97 & 0 & 0 & 206 & 217 \\
\hline Dried sugar beet pulp ${ }^{3}$ & 0 & 0 & 0 & 60 & 69 \\
\hline Soybean meal ${ }^{4}$ & 84 & 150 & 144 & 61 & 67 \\
\hline Wheat straw & 20 & 152 & 49 & 81 & 8 \\
\hline Urea & 4 & 1 & 1 & 3 & 3 \\
\hline Vitamins and minerals & 20 & 16 & 15 & 18 & 17 \\
\hline \multicolumn{6}{|c|}{ Nutrient composition ( $\mathrm{g} / \mathrm{kg}$ of $\mathrm{DM}$ ) } \\
\hline $\mathrm{DM}(\mathrm{g} / \mathrm{kg}$ of product) & 418 & 514 & 459 & 460 & 433 \\
\hline Crude ash & 82 & 64 & 62 & 92 & 94 \\
\hline $\mathrm{CP}$ & 137 & 131 & 133 & 139 & 148 \\
\hline Crude fat & 33 & 28 & 30 & 30 & 31 \\
\hline NDF & 419 & 414 & 372 & 461 & 433 \\
\hline $\mathrm{ADF}$ & 237 & 241 & 213 & 253 & 232 \\
\hline ADL & 20 & 22 & 18 & 24 & 19 \\
\hline Starch & 124 & 182 & 216 & 7 & 7 \\
\hline Sugar & 62 & 38 & 39 & 85 & 91 \\
\hline $\mathrm{IDP}^{5}$ & 79 & 77 & 81 & 84 & 91 \\
\hline $\mathrm{RDPB}^{6}$ & 7.8 & 11.8 & 9.3 & 1.1 & 1.8 \\
\hline Net energy $(\mathrm{MJ} / \mathrm{kg} \text { of } \mathrm{DM})^{7}$ & 6.4 & 6.1 & 6.5 & 6.3 & 6.5 \\
\hline
\end{tabular}
energy level (low) fed from wk 8 to 44 postpartum

${ }^{1}$ Chemical composition of grass silage (g/kg of DM, unless otherwise stated): DM $410 \mathrm{~g} / \mathrm{kg}$ of product, crude ash 111, CP 140, crude fat 42, NDF 458, ADF 258, ADL 17, starch 6, sugar 123, intestinal digestible protein (IDP) 70, RDP balance (RDPB) 5.7, net energy (NE) $6.4 \mathrm{MJ} / \mathrm{kg}$ of DM.

${ }^{2}$ Chemical composition of corn silage (g/ $\mathrm{kg}$ of DM, unless otherwise stated) DM $354 \mathrm{~g} / \mathrm{kg}$ of product, crude ash 49, CP 66, crude fat 30, NDF 383, ADF 218, ADL 18, starch 344, sugar 3, IDP 48, RDPB -36, NE 6.8 $\mathrm{MJ} / \mathrm{kg}$ of DM.

${ }^{3}$ Dried sugar beet pulp was fed in the lipogenic rations between May 4, 2015, and May 9, 2016.

${ }^{4}$ Soybean meal was treated with formaldehyde to make it rumen protected.

${ }^{5}$ Calculated according to the Dutch DVE/OEB system (Tamminga et al., 1994).

${ }^{6}$ Calculated according to the Dutch DVE/OEB system (Tamminga et al., 1994).

${ }^{7}$ Calculated according to the Dutch VEM system (Van Es, 1975). Net energy, IDP, and RDPB values for grass silage, corn silage, and sugar beet pulp were based on near-infrared spectrometry (Blgg AgroXpertus, Wageningen, the Netherlands). Values for IDP, RDPB, and NE of soybean meal were obtained from the manufacturer (Agrifirm, Apeldoorn, the Netherlands). Values for wheat straw and urea were obtained from CVB Feed Tables (CVB, 2011). 
$1 \mathrm{~h}$ before the morning feeding. Blood $(10 \mathrm{~mL})$ was collected from the coccygeal vein into evacuated EDTA tubes (Vacuette, Greiner BioOne, Kremsmunster, Aus-

Table 2. Ingredient and nutrient composition of the standard and experimental concentrates

\begin{tabular}{|c|c|c|}
\hline Item & Standard & Experimental \\
\hline \multicolumn{3}{|l|}{ Ingredient $(\mathrm{g} / \mathrm{kg})$} \\
\hline Palm kernel, expeller & 131 & 179 \\
\hline Corn & 206 & 44 \\
\hline Lupine & - & 26 \\
\hline Sugar beet pulp ( $\max 12 \%$ sugar $)$ & 63 & - \\
\hline Citric pulp & 137 & 120 \\
\hline Wheat & 62 & 128 \\
\hline Wheat meal & - & 9 \\
\hline Barley & 20 & - \\
\hline Soybean hulls & - & 169 \\
\hline Soybean meal & 34 & 54 \\
\hline Soybean meal (rumen protected) & 11 & 9 \\
\hline Rapeseed meal & 113 & 45 \\
\hline Rapeseed meal (rumen protected) & 81 & 70 \\
\hline Molasses-cane & 29 & 36 \\
\hline Molasses-beet & 26 & - \\
\hline Protamylasse $^{1}$ & 14 & - \\
\hline Beet vinasses ${ }^{2}$ & 34 & - \\
\hline $\mathrm{Citrocol}^{3}$ & 20 & 35 \\
\hline Linseed oil & - & 9.1 \\
\hline Palm oil & 2.3 & 3.5 \\
\hline Calcium carbonate & 2.6 & 2.1 \\
\hline Sodium chloride & 3.4 & 4.4 \\
\hline Magnesium oxide & 3.9 & 4.1 \\
\hline Urea & 3.9 & 2.7 \\
\hline Vitamin E & 0.6 & 0.9 \\
\hline Selenium & 1.8 & 1.8 \\
\hline Methionine source $^{4}$ & 0.4 & 0.5 \\
\hline \multicolumn{3}{|l|}{ Nutrient composition ( $\mathrm{g} / \mathrm{kg}$ of product) } \\
\hline $\mathrm{DM}$ (g/kg of product) & 883 & 892 \\
\hline $\mathrm{CP}$ & 175 & 171 \\
\hline Ash & 65 & 59 \\
\hline Crude fat & 38 & 41 \\
\hline NDF & 221 & 338 \\
\hline $\mathrm{ADF}$ & 136 & 201 \\
\hline ADL & 31 & 41 \\
\hline Starch & 221 & 118 \\
\hline Sugar & 80 & 77 \\
\hline $\mathrm{IDP}^{5}$ & 105 & 123 \\
\hline $\mathrm{RDPB}^{6}$ & 17 & 16 \\
\hline Net energy $(\mathrm{MJ} / \mathrm{kg} \text { of } \mathrm{DM})^{7}$ & 7.5 & 7.5 \\
\hline
\end{tabular}

${ }^{1}$ Protamylasse is potato juice concentrate (Avebe, Veendam, the Netherlands). Chemical composition of protamylasse ( $\mathrm{g} / \mathrm{kg}$ of DM, unless otherwise stated): DM $548 \mathrm{~g} / \mathrm{kg}$ of product, crude ash 290 sugar 57, CP 327, intestinal digestible protein (IDP) 52, RDP balance (RDPB) 228, net energy (NE) $6.2 \mathrm{MJ} / \mathrm{kg}$ of DM.

${ }^{2}$ Chemical composition of beet vinasses (g/ $\mathrm{kg}$ of product): DM 663, crude ash 174, CP 214, sugar 37, NDF 2, ADF 1, IDP 34, RDPB 148, NE $4.1 \mathrm{MJ} / \mathrm{kg}$.

${ }^{3} \mathrm{Citrocol}$ was used as a binding agent in the rations.

${ }^{4}$ Methionine as 2-hydroxy-4-methylthiobutanoic acid isopropyl ester (MetaSmart dry, Adisseo, Antony, France).

${ }^{5}$ Calculated according to the Dutch DVE/OEB system (Tamminga et al., 1994).

${ }^{6}$ Calculated according to the Dutch DVE/OEB system (Tamminga et al., 1994).

${ }^{7}$ Net energy, calculated according to the Dutch VEM system (Van Es, 1975). Values for IDP, RDPB, and NE were obtained from the manufacturer (Agrifirm, Apeldoorn, the Netherlands). tria). Blood samples were kept on ice before centrifugation for plasma isolation $\left(3,000 \times g\right.$ for $\left.15 \mathrm{~min}, 4^{\circ} \mathrm{C}\right)$. Plasma samples were stored at $-20^{\circ} \mathrm{C}$. Plasma insulin concentration was measured using kit no. PI-12K from EMD Millipore Corp. (Billerica, MA). Plasma IGF-1 concentration was measured using kit no. A15729 from Beckman Coulter (Fullerton, CA). Plasma GH concentration was measured by RIA as described previously (Vicari et al., 2008).

\section{Calculations}

Energy balance was calculated per week according to the Dutch NE system for lactation (Van Es, 1975), as the difference between intake of VEM and the requirements of VEM for maintenance, milk yield, and pregnancy $(1,000 \mathrm{VEM}=6.9 \mathrm{MJ}$ of $\mathrm{NE})$. According to the VEM system, the daily requirement for maintenance is $42.4 \mathrm{VEM} / \mathrm{kg}^{0.75}$ of BW (where $\mathrm{kg}^{0.75}$ represents metabolic BW) per day, the requirement for milk yield is $442 \mathrm{VEM} / \mathrm{kg}$ of FPCM, and the daily requirement for pregnancy is 450, 850, 1,500, and 2,700 VEM for mo $6,7,8$, and 9 of pregnancy, respectively. Energy intake and EB were expressed in $\mathrm{kJ} / \mathrm{kg}^{0.75}$ of BW per day (Van Es, 1975). Energy efficiency was calculated as follows:

$$
\text { Energy efficiency }=\mathrm{E}_{\mathrm{L}} / \mathrm{NE}_{\mathrm{I}} \text {, }
$$

where $\mathrm{E}_{\mathrm{L}}=$ milk energy output $(\mathrm{kJ} / \mathrm{d})$ and $\mathrm{NE}_{\mathrm{I}}=\mathrm{NE}$ intake $(\mathrm{kJ} / \mathrm{d})$.

For the estimation of lactation curve characteristics, Wood's equation [1] was used with FPCM yield $(\mathrm{kg} / \mathrm{d})$ as dependent variable (Wood, 1967). In Wood's incomplete gamma function, $a$ is a scaling factor associated with the initial milk yield, $b$ is the inclining slope up to peak yield, $c$ is the declining slope toward the end of lactation, and $t$ is time expressed in days after calving. Estimates of $a, b$, and $c$ were obtained from Wood's equation by fitting weekly milk production data from the lactation curve of 305-d for each cow in a nonlinear regression model (PROC NLIN, SAS 9.3, SAS Institute, 2011). Variables from Wood's equation were excluded from analyses for 4 cows because $b$ was negative for these animals. Persistency of peak milk yield $(S)$ was calculated using equation [2]. Day of peak milk yield was calculated using equation [3]. Peak milk yield was calculated using equation [1] with $\mathrm{t}=$ day of peak milk yield. The relative rate of decline of milk yield at the midway point between day of peak milk yield and end of lactation was calculated using equation [4], in which $t f$ is d 305 in milk (Dijkstra et al., 2010):

$$
\operatorname{FPCM}(\mathrm{kg} / \mathrm{d})=a \mathrm{t}^{b} \mathrm{e}^{-c t},
$$




$$
S=\ln c^{-(b+1)},
$$

Day of peak milk yield $=b / c$,

Relative rate of decline $(/ d)=2 b c /(b+c t f)-c$. [4]

\section{Statistical Analyses}

For the current study, 20 of 130 cows were excluded from the data set because of an unplanned DP for cows assigned to a 0 -d DP $(\mathrm{n}=4)$, because they were fed an incorrect concentrate level postpartum $(\mathrm{n}=5)$, because of stealing from a different basal ration than assigned $(\mathrm{n}=3)$, or having less than 200 DIM of milk yield records $(\mathrm{n}=8)$. The final data set consisted of full lactation data of 110 cows (53 of parity 2 and 57 of parity $\geq 3$ ). Preliminary analysis showed that repeated use of 6 cows in this experiment did not affect the results of this study. Statistical analyses were performed using repeated-measures analyses in a mixed linear model (PROC MIXED) with cow as the repeated subject. A first-order autoregressive covariance matrix was the best fit according to Akaike's corrected information criterion and was used to account for within-cow variation. Results are presented as least squares means and standard errors (LSM $\pm \mathrm{SE}$ ). The natural logarithm was calculated for plasma GH concentration to approximate normality.

Milk production, milk composition, feed intake, EB, BW, BW gain, and plasma hormones were analyzed in a mixed linear model with fixed effects of ration $(\mathrm{G}$ or L), transition treatment [0-d DP(low), 0-d DP(std), 30 -d DP(std)], parity $(2, \geq 3$ ), wk after calving (wk 1 through 44), and their 2-way interactions included in the model (Model 1). Plasma insulin, IGF-1, and GH concentration were measured once every 2 wk between wk 11 and 44 and were averaged per 2 wk. Body condition score was analyzed with model 1 , with the exception of the fixed effect of month after calving instead of week after calving.

Variables $a, b, c, S$, day of peak lactation, peak milk yield, the relative rate of decline in milk yield, total lactation yield, and days to conception were analyzed in a mixed linear model, with fixed effects of ration $(\mathrm{G}$ or L), transition treatment [0-d DP(low), 0-d DP(std), $30-\mathrm{d} \mathrm{DP}(\mathrm{std})]$, postpartum parity $(2, \geq 3)$, and their 2 -way interactions included in the model (Model 2). The proportion of cows pregnant within 44 wk was defined as the proportion of cows successfully inseminated within $44 \mathrm{wk}$ of lactation. Pregnancy was analyzed using model 2 with a binary distribution and the default logit link function in a mixed linear regression model (PROC GLIMMIX). The number of services per preg- nancy according to Fetrow et al. (1990) was analyzed using model 2. To evaluate the correlation of lactation curve characteristics with EB and plasma hormones, a Pearson correlation (PROC CORR) was used. The average EB and plasma insulin, IGF-1 and GH concentrations between wk 1 and 7 and wk 8 and 44 were analyzed separately with $a, b, c, S$, and the relative rate of decline in milk yield. Significance was declared at $P$ $<0.05$ and trends at $0.05 \leq P<0.10$.

\section{RESULTS}

\section{Milk Production}

Milk, lactose, and protein yields were greater for cows fed a $\mathrm{G}$ ration than for cows fed an $\mathrm{L}$ ration $(P$ $<0.05$ ), whereas ration did not affect fat yield (Table $3)$. Milk yield and composition did not differ between cows fed a low or standard energy level after a 0-d DP. Milk, FPCM, lactose, and protein yields were greater for cows with a 30-d DP than for cows with a 0-d DP from wk 1 to 44 of lactation $(P<0.01)$. Fat yield was greater for cows with a 30-d DP than for cows with a 0 -d DP $(P<0.01)$, but did not differ between cows in $0-\mathrm{d} \mathrm{DP}$ (low) and 30-d DP(std) in wk 2, 3, and 4 of lactation, or between cows in $0-\mathrm{d} \mathrm{DP}(\mathrm{std})$ and $30-\mathrm{d}$ DP(std) in wk 2 through 9 of lactation $(P \geq 0.05)$. Milk lactose content was greater in cows of parity 2 $(4.53 \pm 0.02 \%)$ compared with cows of parity $\geq 3(4.46$ $\pm 0.02 \%)(P<0.01)$.

An interaction of ration with transition treatment [i.e., 0-d DP(low), 0-d DP(std), or 30-d DP(std)] was present for milk lactose content (Figure 1a) and milk fat content (Figure 1b). Compared with an L ration, a $\mathrm{G}$ ration resulted in a greater milk lactose content for cows in 0 -d DP(low) $(P<0.05)$, but did not affect milk lactose content for cows on other transition treatments $(P \geq 0.05)$. A $\mathrm{G}$ ration resulted in a lower milk fat content than an $\mathrm{L}$ ration for cows in 0 -d DP(std) or 30-d DP(std) $(P<0.01)$ but did not affect milk fat content for cows in 0 -d DP(low) $(P \geq 0.05)$. The interaction of ration and parity indicated a greater milk fat content (Figure 1c) for cows of parity 2 compared with parity $\geq 3$ when fed an $\mathrm{L}$ ration $(P<0.05)$ but not when fed a $\mathrm{G}$ ration $(P \geq 0.05)$. An interaction of transition treatment with parity was present for milk fat (Figure 1d) and protein contents (Figure 1e). Cows of parity 2 in transition treatment 0 -d $\mathrm{DP}$ (low) had a greater milk fat content than cows of parity $\geq 3(P<0.05)$, whereas an effect of parity was not present for the other transition treatments $(P \geq 0.05)$. Milk protein content was lower for cows of parity $\geq 3$ after a 0 -d DP(low) or 0 -d DP(std) compared with cows of parity $2(P<0.05)$, and did not differ between parities after a $30-\mathrm{d}$ DP(std) 


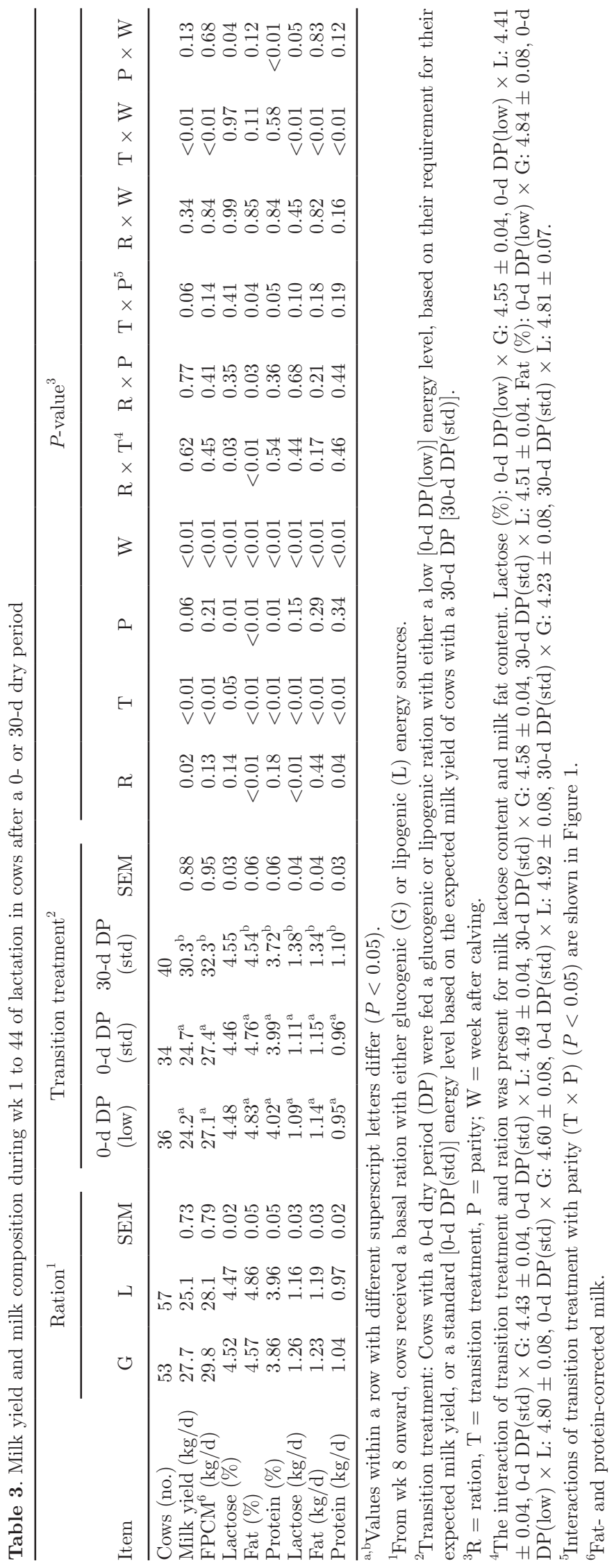

$(P \geq 0.05)$. An interaction of transition treatment with week after calving was present for milk yield, FPCM yield (Figure 2a), lactose yield (Figure 2b), fat yield (Figure 2c), and protein yield (Figure 2d) $(P<0.05)$. An interaction of parity with week after calving was present for milk lactose (Figure 2e) and protein content (Figure 2f) $(P<0.05)$.

\section{DMI, EB, and Hormones}

Energy intake and plasma IGF-1 concentration were greater for cows fed a $\mathrm{G}$ ration compared with those fed an $\mathrm{L}$ ration $(P<0.05$; Table 4$)$. However, EB was not affected by ration. In line with the experimental contrast made, an interaction was present between transition treatment and week for concentrate intake. Concentrate intake was lower in cows in 0 -d DP(low) than in cows in 0-d DP(std) or 30-d DP(std) from wk 4 to 30 in lactation $(P<0.01)$. Energy intake and EB were lower for cows in 0-d DP(low) than in cows in 0-d DP(std). Dietary energy level did not affect BW, BCS, or plasma insulin, IGF-1 or GH concentrations for cows with a 0 -d DP, but cows in 0-d DP(low) had a lower weekly BW gain than cows in $0-d \mathrm{DP}($ std). Omitting the dry period reduced energy intake, energy efficiency, and plasma GH concentration [only for cows in 0-d DP(std)], and increased EB, BW, weekly BW gain, and plasma insulin and IGF-1 concentrations [only for cows in $0-\mathrm{d} \mathrm{DP}(\mathrm{std})]$ compared with a $30-\mathrm{d} \mathrm{DP}(P<0.05)$. Cows of parity 2 had a lower BW $(661 \pm 8$ vs. $716 \pm$ $8 \mathrm{~kg})$, and greater weekly BW gain $(2.3 \pm 0.1$ vs. 1.3 $\pm 0.1 \mathrm{~kg} / \mathrm{wk}$ ) and plasma IGF-1 concentration (167.7 \pm 5.2 vs. $147.8 \pm 5.2 \mathrm{ng} / \mathrm{mL})$ than cows of parity $\geq 3$ $(P<0.01)$.

Dry matter intake, basal ration intake, BCS, and plasma insulin and GH concentrations were affected by an interaction of ration with transition treatment. Cows in 0-d DP(low) or 30-d DP(std) fed a G ration had a greater DMI (Figure 3a) and basal ration intake than cows fed an $\mathrm{L}$ ration $(P<0.05)$. The $\mathrm{G}$ ration, compared with the $\mathrm{L}$ ration, increased BCS (Figure $3 \mathrm{~b}$ ) and plasma insulin concentration (Figure 3c) of cows in 0-d DP(std), and decreased plasma GH (Figure 3d) of cows in 0-d DP(std) and 30-d DP(std), but did not affect cows in other transition treatments. Energy intake, energy output in milk, and EB were affected by an interaction of transition treatment with parity, and DMI and basal ration intake were affected by an interaction of ration with parity. Cows of parity 2 had greater energy intake (Figure 3e) and energy output in milk (Figure 3f), but a lower EB (Figure 3g), than cows of parity $\geq 3$ after a 30 -d DP $(P<0.05)$, but parity did not affect the EB of cows with a 0 -d DP. The DMI (Figure $3 \mathrm{~h}$ ) and basal ration intake were affected by 

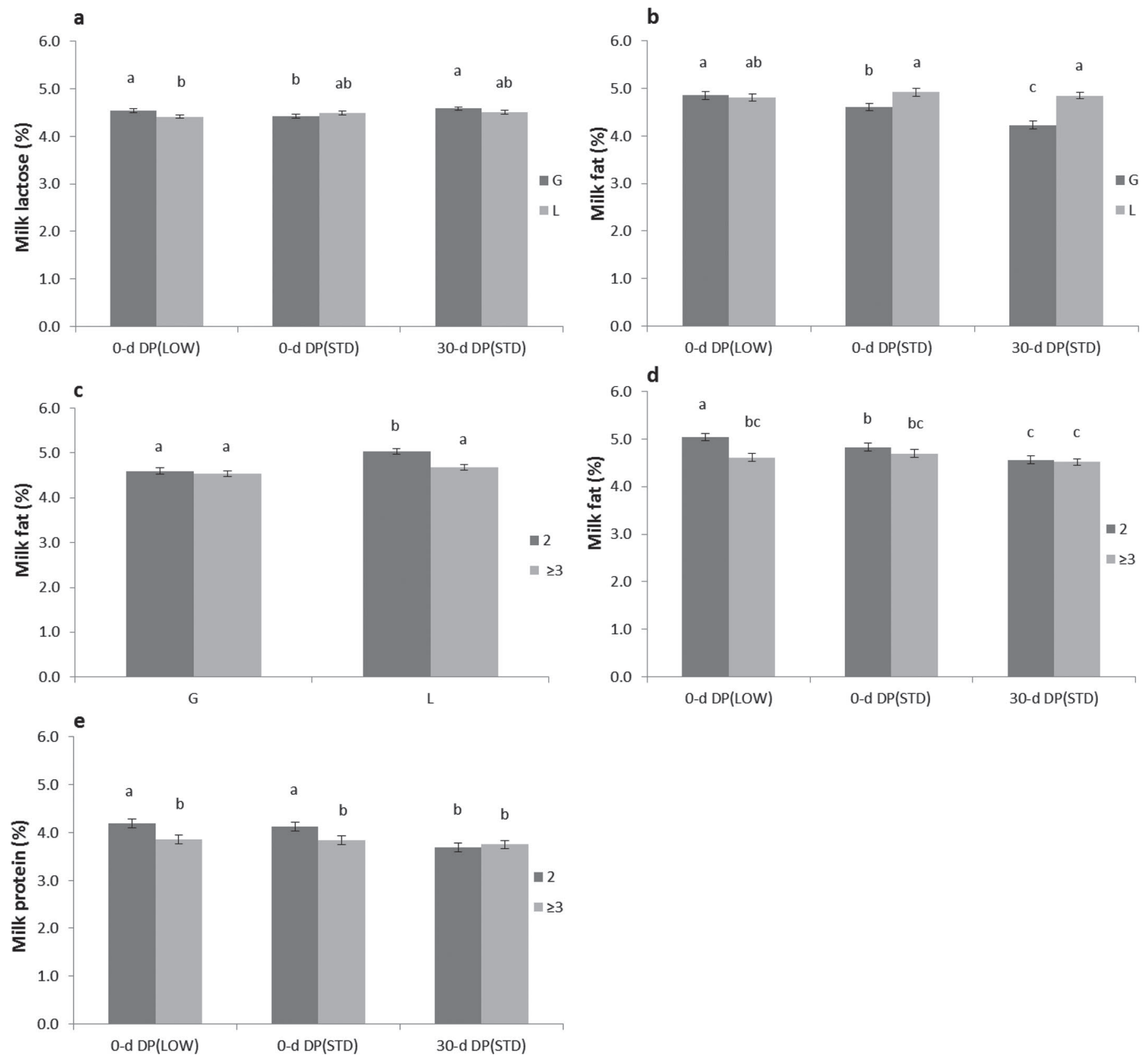

Figure 1. The effect of the interaction between transition treatment \{cows with a 0-d dry period (DP) fed a low energy level [0-d DP(low)], based on their requirement for their expected milk yield, or a standard [0-d DP(std)] energy level that cows with a 30-d DP [30-d DP(std) received based on the requirement for their expected milk yield\} and postpartum ration [glucogenic (G; dark gray) or lipogenic (L; light gray)] fed in wk 8 to 44, for milk lactose content (a), milk fat content (b), the interaction between ration and parity for milk fat content (c), and the interaction between transition treatment and parity ( 2 in dark gray or $\geq 3$ in light gray) for milk fat content (d) and milk protein content (e). Values with different letters $(\mathrm{a}-\mathrm{c})$ differ $(P<0.05)$. Results are presented as LSM \pm SEM.

an interaction of ration with parity. The interaction of transition treatment with week after calving was present for DMI (Figure 4a), concentrate intake, basal ration intake, energy intake (Figure 4b), energy output in milk (Figure 4c), BW (Figure 4d), and weekly BW gain $(P<0.05)$, but not for EB (Figure 4e) or concentra- tions of plasma insulin (Figure 4f), IGF-1 (Figure 4g), or GH (Figure 4h) $(P \geq 0.05)$. The interaction of ration with week after calving was present for DMI (Figure 4i) and basal ration intake $(P<0.05)$. The interaction of parity with week after calving was present for energy efficiency, BW, and weekly BW gain $(P<0.01)$. 


\section{Lactation Curve Characteristics}

Ration did not affect initial FPCM yield $(a)$, the decreasing slope of the lactation curve $(c)$, lactation persistency $(S)$, or the relative rate of decline of FPCM yield midway between peak lactation and $44 \mathrm{wk}$ in lactation (Table 5). An interaction was present between ration and transition treatment on the increasing slope of the lactation curve $(b)(P=0.01)$. A $\mathrm{G}$ ration resulted in a greater increasing slope $(b)$ in cows with a 0 -d DP(std) but in a lower $b$ in cows with a $30-d$ $\mathrm{DP}(\mathrm{std})$; it did not affect cows with a 0 -d DP(low) (Figure 5a). Dietary energy level did not affect initial FPCM yield $(a)$, the decreasing slope of the lactation curve $(c)$, lactation persistency $(S)$, or the relative rate of decline of FPCM yield. Initial FPCM yield $(a)$, peak

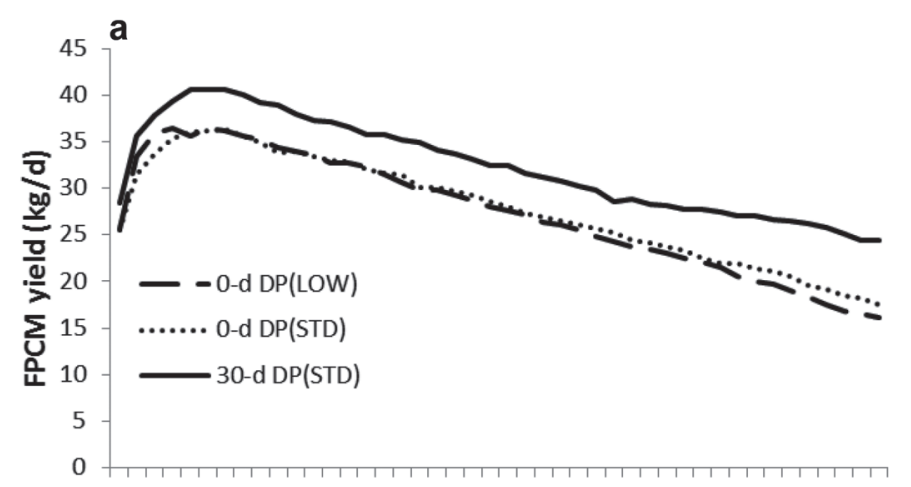

$1 \quad 3 \quad 5 \quad 7 \quad 9 \quad 1113151719212325272931333537394143$
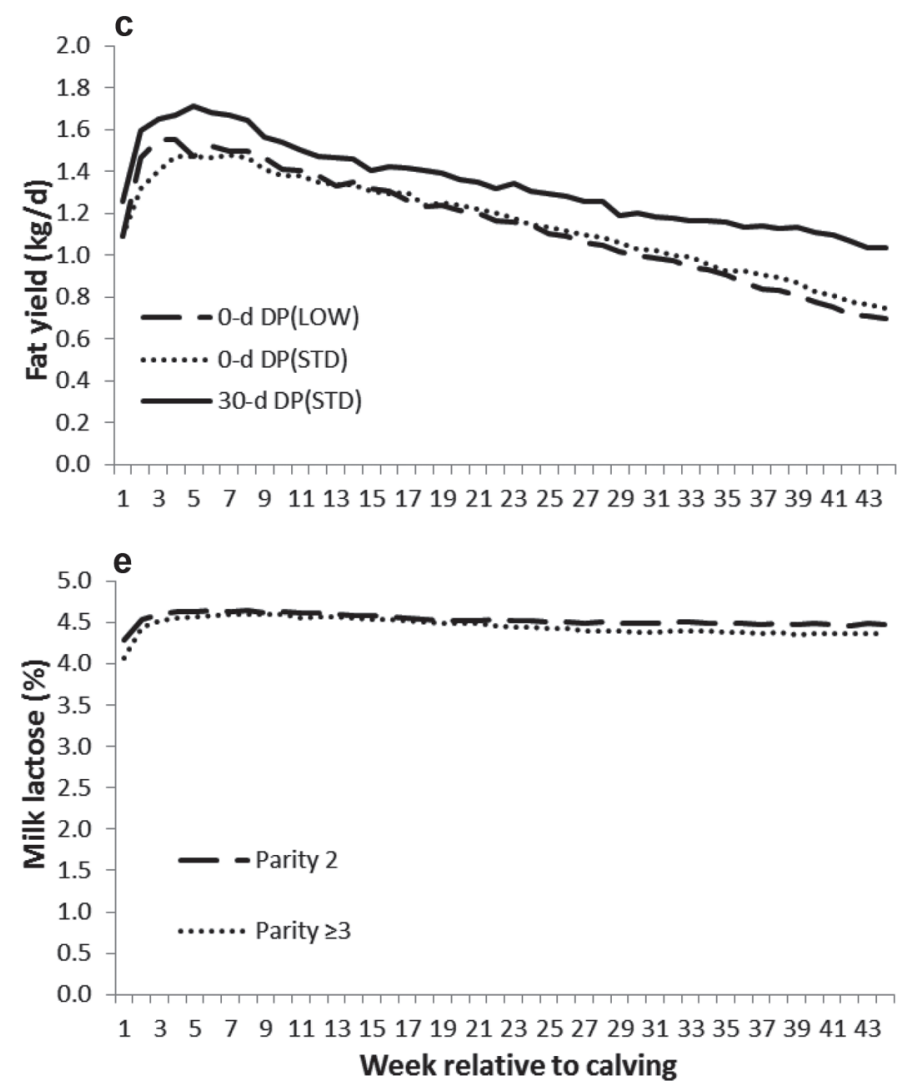
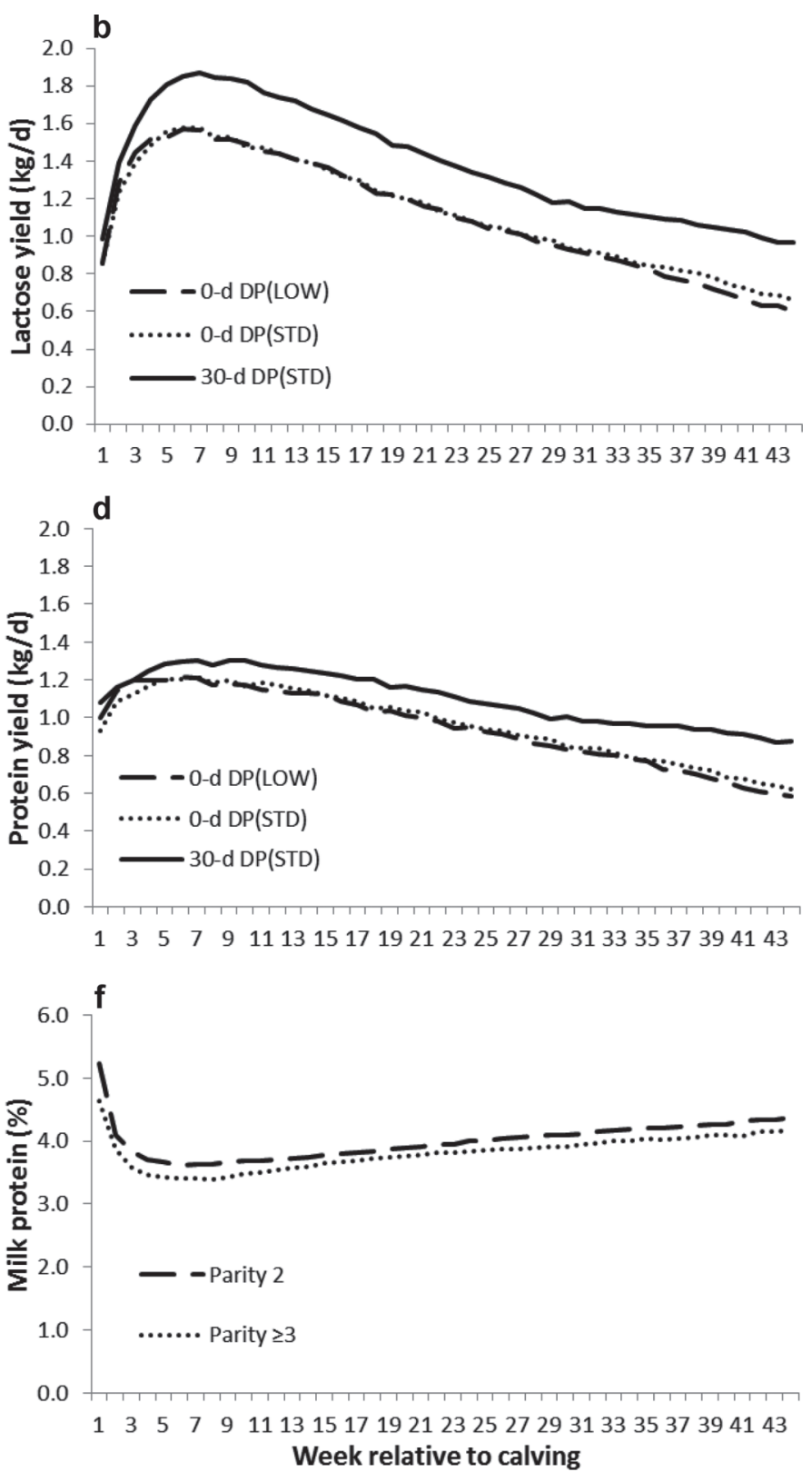

Figure 2. Yield $(\mathrm{kg} / \mathrm{d})$ of fat- and protein-corrected milk (FPCM, a), lactose (b), fat (c), and protein (d) in cows with different dry period (DP) lengths and dietary energy levels \{cows with a 0-d DP were fed a glucogenic or lipogenic ration in wk 8-44 with a low [0-d DP(low)] energy level, based on their requirement for their expected milk yield, or a standard [0-d DP(std)] energy level that cows with a 30-d DP [30-d $\mathrm{DP}(\mathrm{std})$ ] received based on the requirement for their expected milk yield\}, and milk lactose (e) and protein (f) content for cows with different parities $(2$ or $\geq 3)$. 


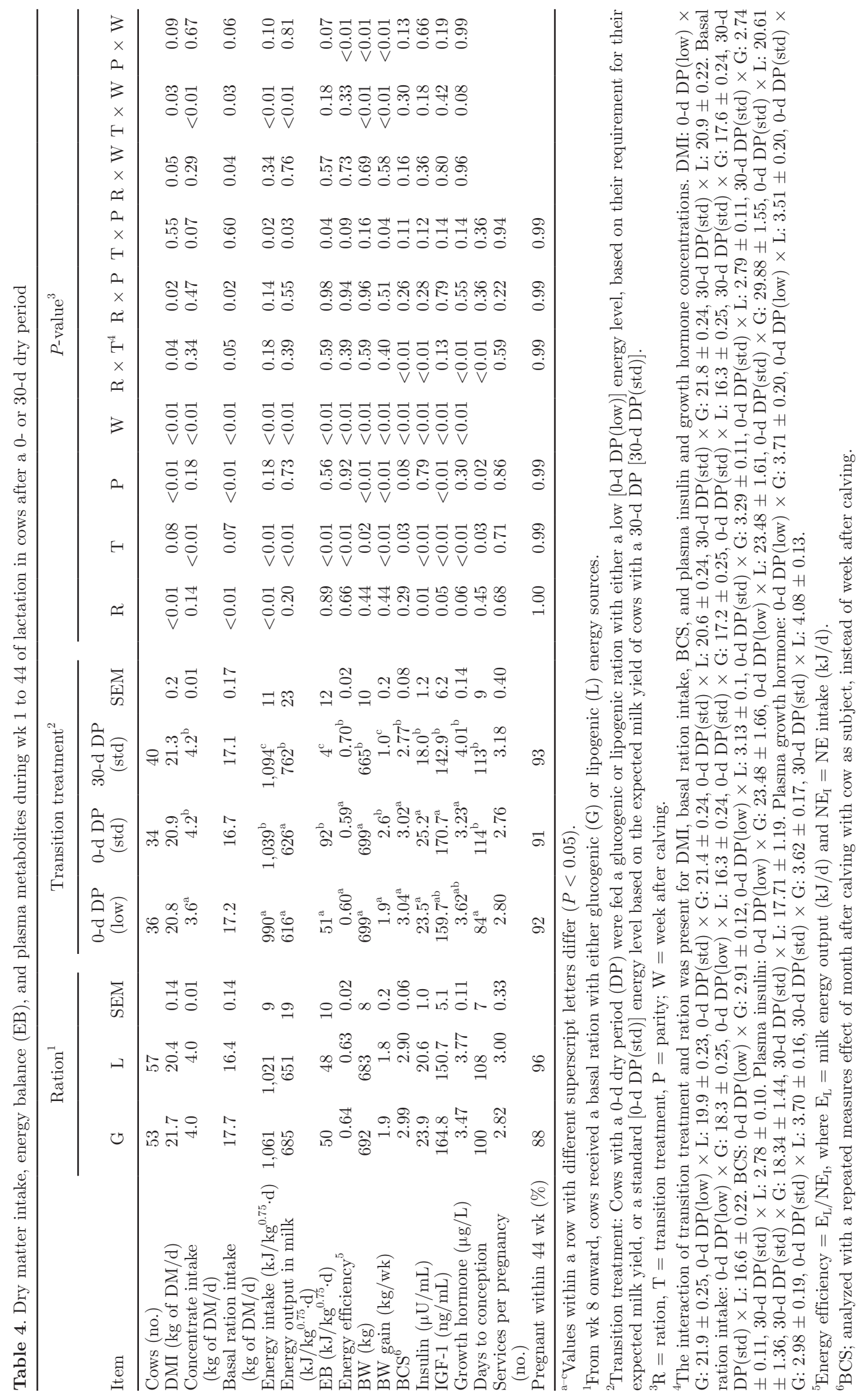



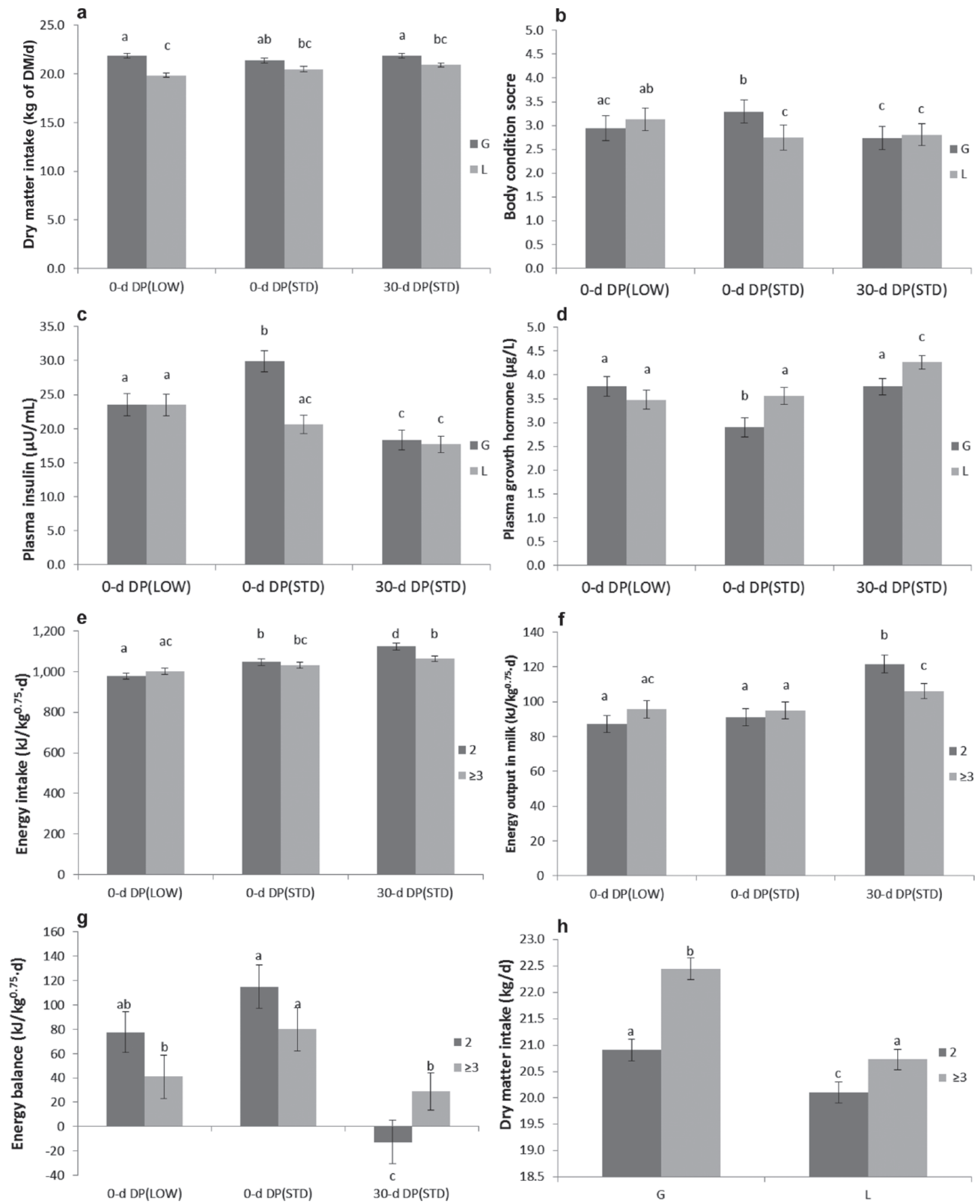

Figure 3. The effect of the interaction between transition treatment \{cows with a 0-d dry period (DP) fed a low energy level [0-d DP(low)], based on their requirement for their expected milk yield, or a standard [0-d DP(std)] energy level that cows with a 30-d DP [30-d DP(std) received based on the requirement for their expected milk yield\} and postpartum ration [glucogenic (G; dark gray) or lipogenic (L; light gray)] fed in wk 8 to 44, or parity (2 in dark gray or $\geq 3$ in light gray) for DMI (a), BCS (b), plasma insulin concentration (c), plasma growth hormone concentration (d), energy intake (e), energy output in milk (f), energy balance (g), and the interaction between ration and parity for DMI (h). Values with different letters $(\mathrm{a}-\mathrm{c})$ differ $(P<0.05)$. Results are presented as LSM \pm SEM. 
FPCPM yield, and total predicted lactation yield were greater for cows with a 30-d DP than in cows with a 0 -d DP $(P<0.05)$. The increasing $(b)$ and decreasing slope $(c)$ of the lactation curve, and the relative rate of decline in FPCM yield were lower for cows with a $30-d$ DP than for cows with a 0 -d DP $(P<0.05)$. Cows of parity 2 had lower peak FPCM yield than cows of parity $\geq 3(35.1 \pm 0.8$ vs. $38.7 \pm 0.8 \mathrm{~kg}$ of $\mathrm{FPCM} / \mathrm{d})$ $(P<0.01)$.

\section{Conception}

The number of services per pregnancy and the proportion of cows pregnant within 44 wk of lactation were not affected by ration, transition treatment, parity, or any of the interactions (Table 4). Days to conception was affected by an interaction between ration and transition treatment. Cows in $0-d \mathrm{DP}(\mathrm{std})$ fed a $\mathrm{G}$ ration and cows with a 30-d DP fed an L ration had a greater number of days to conception than cows in other groups (Figure 5b). Cows in 30-d DP(std) or 0-d DP(std) had more days to conception than cows in 0 -d DP(low) $(P$ $=0.03)$. Cows of parity $\geq 3(116 \pm 8 \mathrm{~d})$ had a greater number of days to conception than cows of parity 2 (91 $\pm 7 \mathrm{~d})(P=0.02)$.

\section{Correlations Between Lactogenic Hormones and Lactation Curve Characteristics}

In wk 1 to 7 , a negative correlation of $\mathrm{EB}$ and plasma insulin and IGF-1 concentrations with initial milk yield (a) and positive correlations of EB and plasma insulin and IGF-1 concentrations with increasing $(b)$ and decreasing slope $(c)$ of the lactation curve were present (Table 6). Additionally, positive correlations of EB and plasma IGF-1 concentration with persistency $(S)$, and negative correlations of $\mathrm{EB}$ and plasma insulin with the relative rate of decline in FPCM yield were present. A positive correlation of the plasma GH concentration with initial milk yield $(a)$ and a negative correlation of the plasma GH concentration with the increasing (b) slope of the lactation curve were present.

In wk 8 to 44, negative correlations of $\mathrm{EB}$ and plasma insulin and IGF-1 concentrations with initial milk yield (a) and the relative rate of decline in FPCM yield, and positive correlations of EB and plasma insulin and IGF1 concentrations with the increasing $(b)$ and decreasing slope $(c)$ of the lactation curve were present (Table 6). There was also a positive correlation of the plasma GH concentration with initial milk yield $(a)$ and a negative correlation of the plasma GH concentration with the increasing (b) slope of the lactation curve.

\section{DISCUSSION}

\section{Milk Yield, DMI, and EB}

Compared with an $\mathrm{L}$ ration, a $\mathrm{G}$ ration fed from wk 7 to 44 in lactation increased milk, lactose, and protein yields and decreased milk fat content. The lower fat content in milk of cows with a $\mathrm{G}$ ration may be a result of dilution due to the greater milk yield, because fat yield was not different between cows with a $\mathrm{G}$ or $\mathrm{L}$ ration. Overall, FPCM yield was not different between cows with a $G$ or $L$ ration. Earlier studies also found an increase in milk fat content and fat yield with a more lipogenic ration in early lactation compared with a glucogenic ration (van Knegsel et al., 2007a; Garnsworthy et al., 2009; Mahjoubi et al., 2009). In the current study, the $\mathrm{L}$ ration was characterized by a much greater proportion of beet pulp and grass silage, and no corn silage, resulting in a greater availability of lipogenic precursors than the $\mathrm{G}$ ration. In cows with a $\mathrm{G}$ ration, the greater milk, lactose, and protein yields may result from the greater availability of glucogenic precursors compared with cows with an L ration. In earlier studies, however, a glucogenic ration in early lactation did not result in an increase in milk, lactose, or protein yields compared with a more lipogenic ration (van Knegsel et al., 2007a; Garnsworthy et al., $2008,2009)$. This difference in effect of a glucogenic ration on milk yield and composition among studies could be explained by the stage of lactation: in the current study, the contrast in dietary energy source was compared during mid and late lactation, whereas in the earlier studies, the lipogenic and glucogenic diets were fed during the first $8 \mathrm{wk}$ (van Knegsel et al., 2007a), between 6 and 10 wk of lactation, or during the first 17 wk of lactation (Garnsworthy et al., 2008, 2009). In contrast with mid- or late-lactation cows, cows in early lactation usually mobilize energy from body reserves, which consists mainly of lipogenic precursors, and may have a relative shortage of glucogenic precursors for fat oxidation, resulting in no extra partitioning of glucogenic nutrients toward the mammary gland, when a glucogenic diet is fed (Davis and Collier, 1985). Moreover, in the current study, cows fed the $\mathrm{G}$ ration had a greater DMI than cows fed the L ration. Also in earlier studies, feeding beet pulp reduced DMI, milk production, and BCS in mid-lactation cows compared with feeding grain (Voelker and Allen 2003). In another study, beet pulp decreased BCS and plasma glucose but increased milk fat and energy content in late lactation (Mahjoubi et al., 2009). The greater observed DMI and milk production and reduced milk fat content of cows fed a $\mathrm{G}$ ration compared with an $\mathrm{L}$ ration is in line with the changes observed upon replacing grass silage 
with corn silage reported by Abrahamse et al. (2008). In the present experiment, where the contrast between glucogenic and lipogenic nutrients was introduced after 49 DIM, no effects on EB were observed, because the extra energy $(+4 \%)$ consumed with the $\mathrm{G}$ ration led to a numerical increase $(+5 \%)$ in milk energy output. Additionally, in the current study, the greater DMI of cows on the G ration may result from the greater DM content of this ration, which may have increased DMI and energy intake, compared with the $\mathrm{L}$ ration. A low DM content of a ration may decrease DMI (Zom et al., 2012).

The lower dietary energy level fed from calving until wk 44 in lactation for cows after a 0-d DP did not affect milk energy output, BW, or BCS but did decrease EB and weekly BW gain. Previous research showed
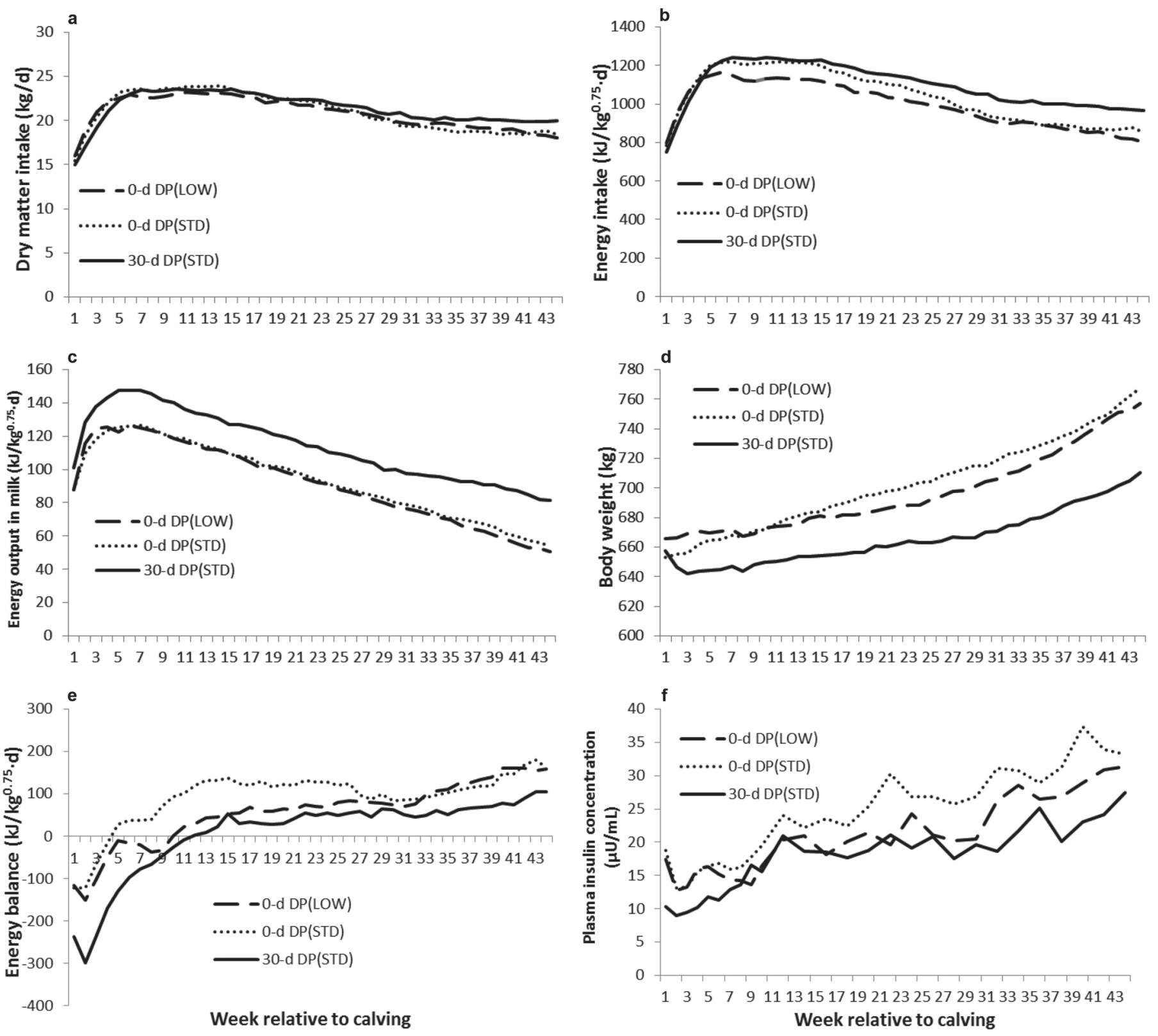

Figure 4. Dry matter intake (a), energy intake (b), energy output in milk (c), BW (d), energy balance (e), plasma insulin (f), plasma IGF$1(\mathrm{~g})$, and plasma GH (h) for cows with different dry period (DP) lengths and dietary energy level \{cows with a 0-d DP were fed a glucogenic or lipogenic ration with a low [0-d DP(low)] energy level, based on their requirement for their expected milk yield, or a standard [0-d DP(std)] energy level that cows with a 30-d DP [30-d DP(std)] received based on the requirement for their expected milk yield\}, and DMI (i) for cows with different postpartum rations [glucogenic $(\mathrm{G})$ or lipogenic $(\mathrm{L})]$ fed in wk 8 to 44 . 
that, in heifers, additional energy intake through concentrate increased peak milk yield and BW (Broster et al., 1975). Another study showed that lower energy intake, through less concentrate, decreased ECM, EB, and BCS (Reist et al., 2003). Additionally, a previous study on extending the lactation in a pasture-based system showed that cows fed a high energy level had greater milk yield and BCS at the end of lactation than cows fed a control ration (Grainger et al., 2009). Comparison of our findings with these previous studies suggest that, in our experiment, cows in 0-d DP(low) did receive sufficient energy for body maintenance and milk production. It should be noted that the contrast in energy intake between low and standard energy groups was smaller than expected. In line with previous studies (e.g., Dieho et al., 2016), cows offered a lower amount of concentrate increased their intake of the basal ration, partly compensating for the lower intake of energy with concentrate. Cows in 0-d DP(std) had a lower BW at calving, but weekly BW gain of cows in $0-\mathrm{d} \mathrm{DP}$ (std) was greater as a result of a greater energy intake, resulting in similar average BW and BCS during the 44-wk experimental period compared with cows in 0 -d DP(low). Weekly BW gain may be a more accurate measure for fattening than average BW or BCS for lactation. Dietary energy level, therefore, can be reduced for cows with a 0-d DP, to aim for zero EB, without detrimental effects on metabolic status or milk production and may reduce fattening and feeding costs.

Cows with a 0-d DP had a 5-kg-lower daily FPCM production $(27.2$ vs. $32.3 \pm 0.8 \mathrm{~kg}$ of $\mathrm{FPCM} / \mathrm{d}$; wk 1-44) than cows with a 30-d DP. This is in line with previous work where cows with a $0-d$ DP $(35.4 \mathrm{~kg}$ of FPCM/d) had a 5-kg-lower FPCM production than cows with a $30-\mathrm{d}$ DP (40.4 kg of FPCM/d) in wk 1 to 14 (van Knegsel et al., 2014) or in wk 1 to 44 (Kok et al., 2016). The consistency in milk production difference between cows with a 0 -d or 30-d DP suggests that a DP length predisposes for a certain milk production capacity during the subsequent lactation.
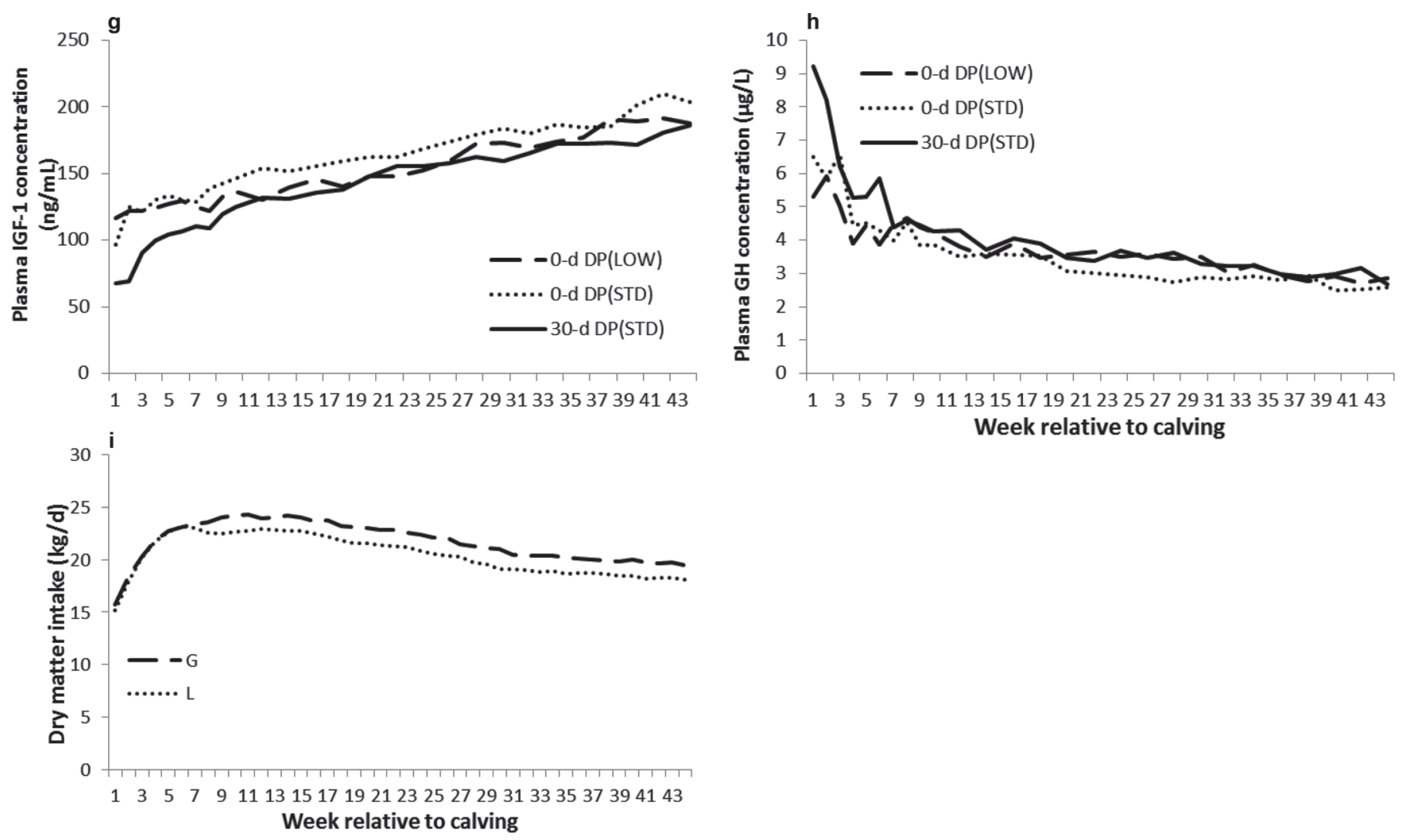

Week relative to calving

Figure 4 (Continued). Dry matter intake (a), energy intake (b), energy output in milk (c), BW (d), energy balance (e), plasma insulin (f), plasma IGF-1 (g), and plasma GH (h) for cows with different dry period (DP) lengths and dietary energy level \{cows with a 0 -d DP were fed a glucogenic or lipogenic ration with a low [0-d DP(low)] energy level, based on their requirement for their expected milk yield, or a standard $[0-\mathrm{d}$ DP (std)] energy level that cows with a 30-d DP [30-d DP(std)] received based on the requirement for their expected milk yield\}, and DMI (i) for cows with different postpartum rations [glucogenic $(\mathrm{G})$ or lipogenic $(\mathrm{L})$ ] fed in wk 8 to 44. 
VAN HOEIJ ET AL.

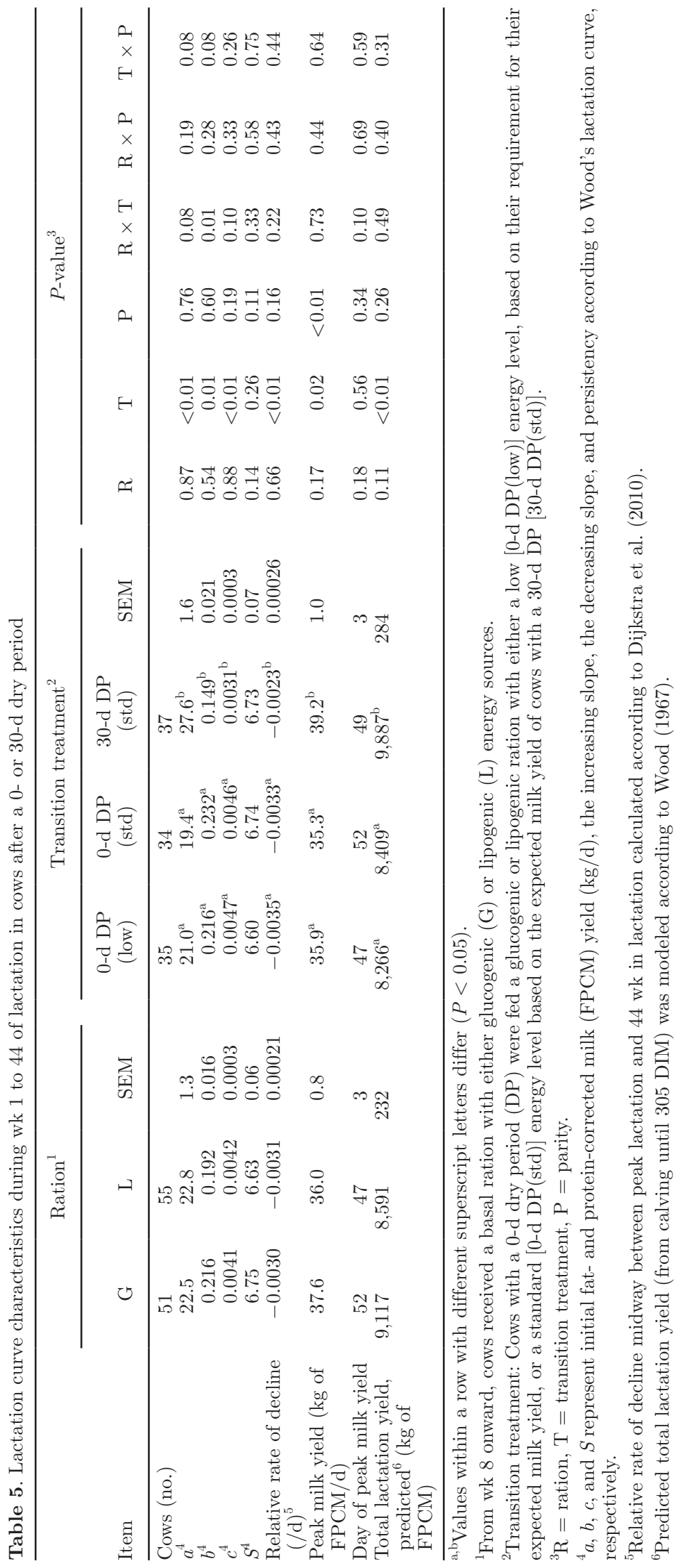



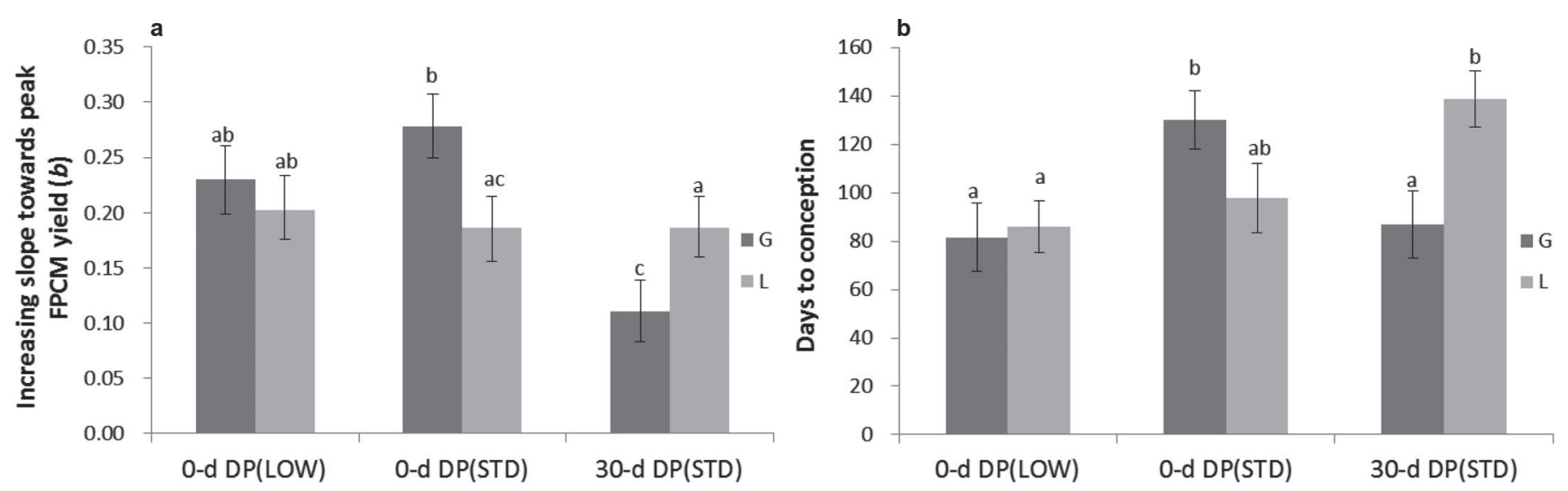

Figure 5. The effect of the interaction between transition treatment \{cows with a 0-d DP fed a low energy level [0-d DP(low)], based on their requirement for their expected milk yield, or a standard [0-d DP(std)] energy level that cows with a 30-d DP [30-d DP(std)] received based on the requirement for their expected milk yield\} and postpartum ration [glucogenic (G; dark gray) or lipogenic (L; light gray)] fed in wk 8 to 44 , for the parameter representing the increasing slope toward peak fat- and protein-corrected milk (FPCM) yield (a) and days to conception (b). Values with different letters $(\mathrm{a}-\mathrm{c})$ differ $(P<0.05)$. Results are presented as LSM $\pm \mathrm{SEM}$.

\section{Lactogenic Hormones}

Cows fed a $\mathrm{G}$ ration had greater plasma insulin concentrations than cows fed the $\mathrm{L}$ ration in the $0-\mathrm{d} \mathrm{DP}(\mathrm{std})$ treatment but not in the other transition treatments. Cows fed a $\mathrm{G}$ ration tended to have a greater IGF-1 concentration and a lower GH concentration (the latter only in standard, not in low), compared with cows fed an $\mathrm{L}$ ration. The tendency to a greater plasma IGF-1 concentration for cows fed the $\mathrm{G}$ ration indicates a more coupled somatotropic axis (Butler et al., 2003; Wathes et al., 2011), resulting in a greater negative feedback on GH release from the pituitary gland (Lucy, 2008). Furthermore, as insulin and GH have antagonistic roles, greater plasma insulin and lower GH concentration in mid and late lactation can be expected to result in fewer nutrients partitioned toward the mammary gland, resulting in reduced milk yield (Hart, 1983). However, in the current study, greater milk yield was observed in cows with a $G$ ration than in cows with an $\mathrm{L}$ ration. Cows with a $\mathrm{G}$ or an $\mathrm{L}$ ration had a positive $\mathrm{EB}$, so it can be hypothesized that the somatotropic axis was coupled for both rations and that feed intake and milk yield were closely linked (Lucy et al., 2009). The greater milk yield in cows with a $G$ ration was, therefore, more likely a result of greater DMI than of a difference in plasma insulin, IGF-1, or GH concentration, compared with cows with an $\mathrm{L}$ ration.

Table 6. Pearson correlation coefficients $(P<0.05)$ of average lactation curve characteristics, plasma hormones, milk yield, and energy balance in wk 1 to 7 and wk 8 to 44

\begin{tabular}{lccccc}
\hline & \multicolumn{5}{c}{ Lactation curve characteristic $^{1}$} \\
\cline { 2 - 6 } Item & $a$ & $b$ & $c$ & $S$ & Rd \\
\hline Weeks 1 to 7 & & & & \\
$\mathrm{~EB}^{2}\left(\mathrm{~kJ} / \mathrm{kg}^{0.75} \cdot \mathrm{d}\right)$ & $-0.65^{* *}$ & $0.47^{* *}$ & $0.30^{* *}$ & $0.30^{* *}$ & $-0.22^{*}$ \\
$\left.\mathrm{Insulin}^{* *} \mu \mathrm{U} / \mathrm{mL}\right)$ & $-0.51^{* *}$ & $0.40^{* *}$ & $0.37^{* *}$ & $\mathrm{NS}$ & $-0.33^{* *}$ \\
$\mathrm{IGF}-1(\mathrm{ng} / \mathrm{mL})$ & $-0.45^{* *}$ & $0.37^{* *}$ & $0.20^{*}$ & $0.29^{* *}$ & $\mathrm{NS}$ \\
$\mathrm{GH}^{2}(\mu \mathrm{g} / \mathrm{L})$ & $0.27^{* *}$ & $-0.25^{*}$ & $\mathrm{NS}$ & $\mathrm{NS}$ & $\mathrm{NS}$ \\
Weeks 8 to 44 & & $0.46^{* *}$ & $0.60^{* *}$ & $\mathrm{NS}$ & $-0.63^{* *}$ \\
$\mathrm{~EB}\left(\mathrm{~kJ} / \mathrm{kg}^{0.75} \cdot \mathrm{d}\right)$ & $-0.40^{* *}$ & $0.39^{* *}$ & $0.48^{* *}$ & $\mathrm{NS}$ & $-0.50^{* *}$ \\
Insulin $(\mu \mathrm{U} / \mathrm{mL})$ & $-0.37^{* *}$ & $0.32^{* *}$ & $0.27^{* *}$ & $\mathrm{NS}$ & $-0.25^{* *}$ \\
$\mathrm{IGF}-1(\mathrm{ng} / \mathrm{mL})$ & $-0.29^{* *}$ & $-0.20^{*}$ & $\mathrm{NS}$ & $\mathrm{NS}$ & $\mathrm{NS}$ \\
GH $(\mu \mathrm{g} / \mathrm{L})$ & $0.24^{*}$ & &
\end{tabular}

${ }^{1}$ Initial milk yield $(a)$, the increasing slope of the lactation curve $(b)$, the declining slope of the lactation curve $(c)$, and persistency $(S)$ were calculated according to Wood (1967); the relative rate of decline at midway point between peak and end of lactation (Rd) was calculated according to Dijkstra et al. (2010).

${ }^{2} \mathrm{~EB}=$ energy balance, $\mathrm{GH}=$ growth hormone.

${ }^{*} P<0.05,{ }^{* *} P<0.01$. 
Reducing dietary energy level for cows with a 0-d DP did not affect lactogenic hormone concentrations. Reducing dietary energy level decreased energy intake and EB, but this effect may not have been large enough to affect concentrations of lactogenic hormones. In several earlier studies, a reduction of dietary energy level through a lower concentrate level was related to lower plasma glucose, insulin, and IGF-1 concentrations (Reist et al., 2003), whereas Kokkonen et al. (2004) reported that plasma insulin concentration was not affected by a lower concentrate level. In a previous study, in wk 1 to 16 of lactation, North American Holstein cows with low supplementation additional to pasture had lower milk yield and plasma IGF-1 concentration and tended to have a greater plasma GH concentration, but the plasma insulin concentration was not affected compared with cows with high supplementation (Lucy et al., 2009). Differences in lactogenic hormone concentrations within studies are likely related to the difference in dietary energy level between treatment groups.

Cows with a 30-d DP had a lower plasma insulin and IGF-1 concentrations and greater $\mathrm{GH}$ concentration than cows with a 0-d DP. Previous studies reported lower insulin (Andersen et al., 2005; Chen et al., 2015) and IGF-1 (Chen et al., 2015) concentrations for cows with a short DP compared with no DP. The difference in lactogenic hormone concentrations between DP lengths reflects the EB of cows with a 30-d DP compared with cows with a $0-\mathrm{d}$ DP and the degree of coupling of the somatotropic axis (Butler et al., 2003).

In general, plasma GH concentration had a low correlation with measures of lactation persistency. Similarly, in an earlier study, plasma GH concentration was only slightly related to lactation persistency (Sorensen and Knight, 2002). Administration of exogenous GH was reported to increase lactation persistency to a greater extent (Van Amburgh et al., 1997; Bauman, 1999). The difference in effect of endogenous and exogenous $\mathrm{GH}$ on lactation persistency could be related to a difference in dose between endogenously synthesized versus exogenously administered GH. In a previous study, exogenous administration of bST resulted in a 2.4-fold increase of plasma $\mathrm{GH}(14.2$ vs. $6.0 \mathrm{ng} / \mathrm{mL})$ and increased milk yield up to $7 \mathrm{~kg} / \mathrm{d}$ compared with cows not treated with bST (Bilby et al., 2006), whereas, in the current study, the $\mathrm{L}$ ration increased plasma $\mathrm{GH}$ concentration 1.1 times compared with the $\mathrm{G}$ ration. The effect of GH could also be related to the complex relation of exogenous or endogenous GH with IGF-1 as mediator in the somatotropic axis and may depend on differences in the plasma IGF-1 concentration, the local mammary IGF-1 concentration, the presence of IGF1 receptors, and types of and presence of insulin-like growth factor binding proteins (Capuco et al., 2003).

\section{Lactation Curve Characteristics}

We hypothesized that dietary energy source affects lactation curve characteristics through effects of energy source on the plasma insulin, IGF-1, and GH concentrations. The $\mathrm{L}$ ration was expected to result in reduced plasma insulin and IGF-1 and increased plasma GH concentration, because of the lower availability of glucogenic precursors (Voelker and Allen, 2003; Mahjoubi et al., 2009). Indeed, cows fed the $\mathrm{L}$ ration after wk 8 in lactation had a greater plasma GH concentration in the standard groups, as discussed above, but this was not related to effects on characteristics of the lactation curve. Lack of effect of the $\mathrm{L}$ ration on lactation curve characteristics could be due to the lower DMI of these cows. The lower DMI of cows with an $\mathrm{L}$ ration resulted in lesser milk production than for cows with a $\mathrm{G}$ ration, despite GH levels being greater and insulin and IGF-1 levels being lower in cows with an $\mathrm{L}$ ration than in cows with a $\mathrm{G}$ ration. The lack of effect of dietary energy source on lactation curve characteristics could also be related to introduction of ration contrast in wk 8 , and not from calving onward. A previous study shows that feeding a $\mathrm{G}$ or L concentrate from calving to 100 DIM affected day of peak milk yield in an interaction with parity, but peak milk yield or lactation persistency were not affected by dietary energy source (Chen et al., 2016a).

The lower dietary energy level for cows with a 0-d DP did not affect lactation curve characteristics, which is in line with a previous study (Broster et al., 1975). Dietary energy level negatively affects persistency in case of underfeeding (Chilliard, 1992). Feeding the energy level for cows with a $30-d$ DP to cows with a 0-d DP did not affect persistency in the current study. In a previous study, feeding the energy level for cows with a 60-d DP to cows with a 0 -d DP did seem to negatively affect persistency and resulted in spontaneous drying off (Chen et al., 2016a). Additionally, a previous study on extending lactation in a pasture-based system showed that a greater proportion of cows fed a high energy level dried off spontaneously at the end of lactation compared with cows fed a control ration (Grainger et al., 2009).

Our hypothesis was that not only dietary energy source but also DP length affects lactation curve characteristics. Cows with a 30-d DP had a higher initial milk yield, lower increasing and declining slopes of the lactation curve, and greater total milk yield. In cows with a $30-d$ DP, the decreasing slope of the lactation curve $(c)$ and the relative rate of decline $(\mathrm{Rd})$, as measures of persistency, were smaller, indicating greater persistency than in cows with a $0-d$ DP. This is in line with a previous study that showed greater 
persistency in cows after a short DP compared with cows with an omitted DP (Mantovani et al., 2010), but is in contrast to another study that showed no effect of DP length on persistency (Chen et al., 2016a). Lactation persistency in the different studies was measured using different variables, which may explain the contrasting results. During the dry period, renewal and regeneration of secretory udder cells occurs (Capuco et al., 1997; Martignani et al., 2014), which may help to explain the difference in persistency between the 0 - $d$ DP and 30-d DP in the present study. Lack of sufficient time to renew secretory cells in cows with a $0-d$ DP may have resulted in elevated numbers of senescent cells with a lower secretory capacity, which may have been detrimental to milk yield at any time in lactation, including lactation persistency. Grummer and Rastani (2004) hypothesized that the better EB during early lactation for cows with a $0-d$ DP might enable the cow to increase regeneration of udder cells during lactation, resulting in better lactation persistency. However, in the current study, the greater milk yield and lower EB in cows with a 30-d DP were associated with a lower plasma IGF-1, greater plasma GH concentration, and greater nutrient partitioning toward milk yield in these cows than in cows with a 0-d DP (Lucy et al., 2009).

Considering dietary energy source and level and DP length, changes in the plasma GH, IGF-1, and insulin concentrations due to differences in DP length were associated with changes in milk production related to DP length. Thus, the greater magnitude of milk production response to DP length treatment may be related to the fact that a greater plasma GH concentration for cows with a 30-d DP was associated with improved lactation persistency, whereas a greater plasma GH concentration for cows fed an $\mathrm{L}$ ration was not associated with an increase in milk yield or improved lactation persistency. It can also be hypothesized that this difference in the effect of dietary energy source versus DP length treatment on lactation persistency and hormone concentrations could be related to the observed responses in EB. Dry period length did affect EB in this study, whereas dietary energy source did not. Further studies are needed to clarify the difference in effect of management strategies on the relation of the plasma GH concentration with milk yield and lactation persistency.

\section{Parity and Pregnancy}

Other known cow factors that influence lactation persistency are parity and pregnancy. In the current study, plasma IGF-1 was greater in cows of parity 2 than in cows of parity $\geq 3$, which is in line with Miller et al. (2006). Insulin-like growth factor 1 plays an important role in cell survival and as an anti-apoptotic factor in mammary tissue, and may, therefore, result in greater cell survival and greater persistency in cows of parity 2 than in cows of parity $\geq 3$ (Flint and Knight, 1997). In contrast, the plasma GH concentration was not different between parity groups in the current study. In line with plasma GH concentrations, lactation curve characteristics were not affected by parity, whereas previous studies reported greater persistency in primiparous cows compared with multiparous cows (Gengler, 1996; Rehn et al., 2000; Ehrlich, 2011). However, to our knowledge, previous studies did not report the plasma GH concentrations of cows of different parities.

In the current study, cows in 0-d DP(low) were pregnant earlier than cows in 30-d DP(std) or 0-d DP(std). Cows in 0-d DP(low) had a greater EB than cows in 30-d DP(std), which may be beneficial for reproduction in early lactation (Butler and Smith, 1989). However, cows in 0-d DP(std) had an even greater EB, even though the number of days to conception was larger than for the 0-d DP(low) cows. Previous research showed that cows with a 0-d DP had a greater EB and had earlier resumption of cyclicity postpartum than cows with a short or conventional DP (Gümen et al., 2005; Chen et al., 2015). In the current study, cows in 0 -d DP(low) received more straw (i.e., more lipogenic components), which was associated with a numerically lower plasma insulin concentration despite a positive EB compared with cows in 0-d DP(std). A low plasma insulin concentration, combined with a positive EB, was earlier related to more medium-sized follicles, fewer small follicles, and an earlier postovulatory increase of progesterone, resulting in a greater mean plasma progesterone concentration between 3 and $5 \mathrm{~d}$ postovulation compared with cows with a greater plasma insulin concentration (Garnsworthy et al., 2008). In contrast, cows in 0-d DP(std) conceived later than cows in $0-\mathrm{d}$ DP(low) and had numerically greater plasma insulin concentrations in the current study. A greater plasma insulin concentration has been associated with decreased oocyte cleavage rate (Fouladi-Nashta and Campbell, 2006) and more small follicles that will not grow to ovulating follicles and can be considered a measure of reduced fertility (Garnsworthy et al., 2008).

A reduced interval from calving to pregnancy may have reduced persistency later on in lactation in cows in the 0-d DP(low) treatment compared with cows in 30-d DP(std). Pregnancy from 3.5 to 6 mo onward negatively influences milk yield and lactation persistency through feto-placental estrogen that strongly stimulates apoptosis of mammary epithelial cells, which decreases both cell number and secretory capacity (Olori et al., 1997; Brotherstone et al., 2004; Yart et al., 2012). Decrease of lactation persistency is related to increasing plasma estrogen produced by the feto-placental unit (Thatcher 
et al., 1980; Bachman et al., 1988). Estrogen stimulates apoptosis of mammary epithelial cells that decreases both cell number and secretory capacity and results in decreased milk synthesis (Yart et al., 2013; Martignani et al., 2014).

\section{CONCLUSIONS}

A 0-d DP resulted in a lower FPCM yield, greater $\mathrm{EB}$, and greater plasma insulin and IGF-1 concentrations, but decreased lactation persistency compared with a $30-d$ DP. Feeding a ration with a reduced energy level for cows with a 0-d DP did not affect FPCM yield or lactation persistency but reduced $\mathrm{EB}$ and weekly BW gain, which implies a lower chance for fattening of cows with a 0-d DP. Feeding a more glucogenic ration compared with a more lipogenic ration did not affect EB or lactation persistency of cows with different dry period lengths, although milk yield, DMI, and plasma insulin and IGF-1 concentrations were greater and plasma GH concentration tended to be lower.

\section{ACKNOWLEDGMENTS}

The authors thank DairyNL (Zuivel-NL, Zoetermeer, the Netherlands; organization of the Dutch dairy supply chain) and the Dutch Ministry of Economic Affairs (EZ, The Hague, the Netherlands) for financing this study. This study is part of the Public-Private Partnership "Sustainable Dairy Chain" (Duurzame Zuivelketen; the Netherlands). The authors also thank staff of the Dairy Campus (Lelystad, the Netherlands), Rudi Koopmanschap and the Veterinary Physiology Group of the University of Bern (Switzerland) for their technical support and laboratory analyses during the experiment.

\section{REFERENCES}

Abrahamse, P. A., B. Vlaeminck, S. Tamminga, and J. Dijkstra. 2008. The effect of silage and concentrate type on intake behavior, rumen function, and milk production in dairy cows in early and late lactation. J. Dairy Sci. 91:4778-4792. https://doi.org/10.3168/jds 2008-1350.

Andersen, J. B., T. G. Madsen, T. Larsen, K. L. Ingvartsen, and M. O. Nielsen. 2005. The effects of dry period versus continuous lactation on metabolic status and performance in periparturient cows. J. Dairy Sci. 88:3530-3541. https://doi.org/10.3168/jds.S0022 $-0302(05) 73038-1$.

Annen, E. L., R. J. Collier, M. A. McGuire, J. L. Vicini, J. M. Ballam, and M. J. Lormore. 2004. Effect of modified dry period lengths and bovine somatotropin on yield and composition of milk from dairy cows. J. Dairy Sci. 87:3746-3761. https://doi.org/10.3168/ jds.S0022-0302(04)73513-4.

Atashi, H., M. J. Zamiri, and M. Dadpasand. 2013. Association between dry period length and lactation performance, lactation curve, calf birth weight, and dystocia in Holstein dairy cows in Iran. J. Dairy Sci. 96:3632-3638. https://doi.org/10.3168/jds.2012 $-5943$.
Bachman, K. C., M. J. Hayen, D. Morse, and C. J. Wilcox. 1988. Effect of pregnancy, milk yield, and somatic cell count on bovine milk fat hydrolysis. J. Dairy Sci. 71:925-931. https://doi.org/10 .3168/jds.S0022-0302(88)79638-1.

Bauman, D. E. 1999. Bovine somatotropin and lactation: From basic science to commercial application. Domest. Anim. Endocrinol. 17:101-116. https://doi.org/10.1016/s0739-7240(99)00028-4.

Berelowitz, M., M. Szabo, L. A. Frohman, S. Firestone, L. Chu, and R. L. Hintz. 1981. Somatomedin-C mediates growth hormone negative feedback by effects on both the hypothalamus and the pituitary. Science 212:1279-1281. https://doi.org/10.1126/science .6262917 .

Bilby, T. R., A. Sozzi, M. M. Lopez, F. T. Silvestre, A. D. Ealy, C. R. Staples, and W. W. Thatcher. 2006. Pregnancy, bovine somatotropin, and dietary n-3 fatty acids in lactating dairy cows: I. Ovarian, conceptus, and growth hormone-insulin-like growth factor system responses. J. Dairy Sci. 89:3360-3374. https://doi.org/10.3168/jds .S0022-0302(06)72373-6.

Broster, W. H., J. V. Broster, T. Smith, and J. W. Siviter. 1975. Experiments on the nutrition of the dairy heifer: IX. Food utilization in lactation. J. Agric. Res. 84:173-186.

Brotherstone, S., R. Thompson, and I. M. S. White. 2004. Effects of pregnancy on daily milk yield of Holstein-Friesian dairy cattle. Livest. Prod. Sci. 87:265-269. https://doi.org/10.1016/j.livprodsci 2003.07.014.

Butler, S. T., A. Marr, S. Pelton, R. Radcliff, M. Lucy, and W. Butler. 2003. Insulin restores GH responsiveness during lactation-induced negative energy balance in dairy cattle: Effects on expression of IGF-I and GH receptor 1A. J. Endocrinol. 176:205-217. https:// doi.org/10.1677/joe.0.1760205.

Butler, W. R., and R. D. Smith. 1989. Interrelationships between energy balance and postpartum reproductive function in dairy cattle. J. Dairy Sci. 72:767-783. https://doi.org/10.3168/jds.S0022 $-0302(89) 79169-4$.

Cannas, A., A. Nudda, and G. Pulina. 2002. Nutritional strategies to improve lactation persistency in dairy ewes. Pages 17-59 in Proc. 8th Great Lakes Dairy Sheep Symposium, Cornell University, Ithaca, NY, Spooner Agricultural Research Station Publications, Spooner, WI.

Capuco, A. V., R. M. Akers, and J. J. Smith. 1997. Mammary growth in Holstein cows during the dry period: Quantification of nucleic acids and histology. J. Dairy Sci. 80:477-487. https://doi.org/10 .3168/jds.S0022-0302(97)75960-5.

Capuco, A. V., S. E. Ellis, S. A. Hale, E. Long, R. A. Erdman, X. Zhao, and M. J. Paape. 2003. Lactation persistency: Insights from mammary cell proliferation studies. J. Anim. Sci. 81:18-31.

Chen, J., A. Kok, G. J. Remmelink, J. J. Gross, R. M. Bruckmaier, B. Kemp, and A. T. M. van Knegsel. 2016a. Effects of dry period length and dietary energy source on lactation curve characteristics over 2 subsequent lactations. J. Dairy Sci. 99:9287-9299. https:// doi.org/10.3168/jds.2016-11253.

Chen, J., G. J. Remmelink, J. J. Gross, R. M. Bruckmaier, B. Kemp, and A. T. M. van Knegsel. 2016b. Effects of dry period length and dietary energy source on milk yield, energy balance, and metabolic status of dairy cows over 2 consecutive years: Effects in the second lactation. J. Dairy Sci. 99:4826-4838. https://doi.org/10.3168/jds .2015-10742.

Chen, J., N. M. Soede, H. A. van Dorland, G. J. Remmelink, R. M. Bruckmaier, B. Kemp, and A. T. M. van Knegsel. 2015. Relationship between metabolism and ovarian activity in dairy cows with different dry period lengths. Theriogenology 84:1387-1396. https://doi.org/10.1016/j.theriogenology.2015.07.025.

Chilliard, Y. 1992. Physiological constraints to milk production: Factors which determine nutrient partitioning, lactation persistency and mobilization of body reserves. World Rev. Anim. Prod. 27:1926.

CVB. 2011. Chemische samenstellingen en nutritionele waarden van voedermiddelen (in Dutch). Productschap Diervoeder, CBV (Centraal Veevoeder Bureau), The Hague, the Netherlands. 
Davis, S. R., and R. J. Collier. 1985. Mammary blood flow and regulation of substrate supply for milk synthesis. J. Dairy Sci. 68:10411058. https://doi.org/10.3168/jds.S0022-0302(85)80926-7.

de Feu, M. A., A. C. Evans, P. Lonergan, and S. T. Butler. 2009. The effect of dry period duration and dietary energy density on milk production, bioenergetic status, and postpartum ovarian function in Holstein-Friesian dairy cows. J. Dairy Sci. 92:6011-6022. https://doi.org/10.3168/jds.2009-2374.

Dieho, K., A. Bannink, I. A. L. Geurts, J. T. Schonewille, G. Gort, and J. Dijkstra. 2016. Morphological adaptation of rumen papillae during the dry period and early lactation as affected by rate of increase of concentrate allowance. J. Dairy Sci. 99:2339-2352. https://doi.org/10.3168/jds.2015-9837.

Dijkstra, J., S. Lopez, A. Bannink, M. S. Dhanoa, E. Kebreab, N. E. Odongo, M. H. Nasri, U. K. Behera, D. Hernandez-Ferrer, and J. France. 2010. Evaluation of a mechanistic lactation model using cow, goat and sheep data. J. Agric. Sci. 148:249-262. https://doi org/10.1017/S0021859609990578.

Ehrlich, J. L. 2011. Quantifying shape of lactation curves, and benchmark curves for common dairy breeds and parities. Bovine. Pract. 45:88-95.

Ferguson, J. D., D. T. Galligan, and N. Thomsen. 1994. Principal descriptors of body condition in Holstein cows. J. Dairy Sci. 77:26952703. https://doi.org/10.3168/jds.S0022-0302(94)77212-X.

Fetrow, J., D. McClary, R. Harman, K. Butcher, L. Weaver, E. Studer, J. Ehrlich, W. Etherington, W. Guterbock, D. Klingborg, J. Reneau, and N. Williamson. 1990. Calculating selected reproductive indices: Recommendations of the American Association of Bovine Practitioners. J. Dairy Sci. 73:78-90. https://doi.org/10.3168/jds .S0022-0302(90)78649-3.

Flint, D. J., and C. H. Knight. 1997. Interactions of prolactin and growth hormone $(\mathrm{GH})$ in the regulation of mammary gland function and epithelial cell survival. J. Mammary Gland Biol. Neoplasia 2:41-48. https://doi.org/10.1023/a:1026321529451.

Fouladi-Nashta, A. A., and K. H. S. Campbell. 2006. Dissociation of oocyte nuclear and cytoplasmic maturation by the addition of insulin in cultured bovine antral follicles. Reproduction 131:449-460. https://doi.org/10.1530/rep.1.00581.

Garnsworthy, P. C., A. A. Fouladi-Nashta, G. E. Mann, K. D. Sinclair, and R. Webb. 2009. Effect of dietary-induced changes in plasma insulin concentrations during the early post partum period on pregnancy rate in dairy cows. Reproduction 137:759-768. https:// doi.org/10.1530/REP-08-0488.

Garnsworthy, P. C., A. Lock, G. E. Mann, K. D. Sinclair, and R. Webb. 2008. Nutrition, metabolism, and fertility in dairy cows: 1. Dietary energy source and ovarian function. J. Dairy Sci. 91:38143823. https://doi.org/10.3168/jds.2008-1031.

Gengler, N. 1996. Persistency of lactation yields: A review. Pages 8796 in Proc. International Workshop on Genetic Improvement of Functional Traits in Cattle. Interbull Bull., Gembloux, Belgium. University of Agricultural Sciences, Uppsala, Sweden.

Gong, J. G., W. J. Lee, P. C. Garnsworthy, and R. Webb. 2002. Effect of dietary-induced increases in circulating insulin concentrations during the early postpartum period on reproductive function in dairy cows. Reproduction 123:419-427.

Grainger, C., M. J. Auldist, G. O'Brien, K. L. Macmillan, and C. Culley. 2009. Effect of type of diet and energy intake on milk production of Holstein-Friesian cows with extended lactations. J. Dairy Sci. 92:1479-1492. https://doi.org/10.3168/jds.2008-1530.

Grala, T. M., M. C. Lucy, C. V. C. Phyn, A. J. Sheahan, J. M. Lee, and J. R. Roche. 2011. Somatotropic axis and concentrate supplementation in grazing dairy cows of genetically diverse origin. J. Dairy Sci. 94:303-315. https://doi.org/10.3168/jds.2010-3773.

Grummer, R. R., and R. R. Rastani. 2004. Why reevaluate dry period length? J. Dairy Sci. 87:E77-E85. https://doi.org/10.3168/jds .S0022-0302(04)70063-6.

Gümen, A., R. R. Rastani, R. R. Grummer, and M. C. Wiltbank. 2005. Reduced dry periods and varying prepartum diets alter postpartum ovulation and reproductive measures. J. Dairy Sci. 88:2401-2411. https://doi.org/10.3168/jds.S0022-0302(05)72918 -0 .
Hart, I. C. 1983. Endocrine control of nutrient partition in lactating ruminants. Proc. Nutr. Soc. 42:181-194. https://doi.org/10.1079/ PNS19830023.

Hart, I. C., J. A. Bines, and S. V. Morant. 1979. Endocrine control of energy metabolism in the cow: correlations of hormones and metabolites in high and low yielding cows for stages of lactation. J. Dairy Sci. 62:270-277. https://doi.org/10.3168/jds.S0022 -0302(79)83235-X.

Ingvartsen, K. L., R. J. Dewhurst, and N. C. Friggens. 2003. On the relationship between lactational performance and health: Is it yield or metabolic imbalance that cause production diseases in dairy cattle? A position paper. Livest. Prod. Sci. 83:277-308. https:// doi.org/10.1016/S0301-6226(03)00110-6.

ISO. 2013. ISO 9622. Milk and liquid milk products. Guidelines for the application of mid-infrared spectrometry. 2:14. International Organization of Standardization, Geneva, Switzerland.

Kok, A., C. E. van Middelaar, B. Engel, A. T. M. van Knegsel, H. Hogeveen, B. Kemp, and I. J. M. de Boer. 2016. Effective lactation yield: A measure to compare milk yield between cows with different dry period lengths. J. Dairy Sci. 99:2956-2966. https:// doi.org/10.3168/jds.2015-10559.

Kokkonen, T., A. Tesfa, M. Tuori, and L. Syrjala-Qvist. 2004. Concentrate feeding strategy of dairy cows during transition period. Livest. Prod. Sci. 86:239-251. https://doi.org/10.1016/j.livprodsci 2003.09.003.

Lucy, M. C. 2004. Mechanisms linking the somatotropic axis with insulin: Lessons from the postpartum dairy cow. Proc. NZ Soc. Anim. Prod. 64:19-23.

Lucy, M. C. 2008. Functional differences in the growth hormone and insulin-like growth factor axis in cattle and pigs: Implications for post-partum nutrition and reproduction. Reprod. Domest. Anim. 43:31-39. https://doi.org/10.1111/j.1439-0531.2008.01140.x.

Lucy, M. C., G. A. Verkerk, B. E. Whyte, K. A. MacDonald, L. Burton, R. T. Cursons, J. R. Roche, and C. W. Holmes. 2009. Somatotropic axis components and nutrient partitioning in genetically diverse dairy cows managed under different feed allowances in a pasture system. J. Dairy Sci. 92:526-539. https://doi.org/10.3168/ jds.2008-1421.

Mahjoubi, E., H. Amanlou, D. Zahmatkesh, M. Ghelich Khan, and N. Aghaziarati. 2009. Use of beet pulp as a replacement for barley grain to manage body condition score in over-conditioned late lactation cows. Anim. Feed Sci. Technol. 153:60-67. https://doi.org/ 10.1016/j.anifeedsci.2009.06.009.

Mantovani, R., L. Marinelli, L. Bailoni, G. Gabai, and G. Bittante. 2010. Omission of dry period and effects on the subsequent lactation curve and on milk quality around calving in Italian Holstein cows. Ital. J. Anim. Sci. 9:e20 https://doi.org/10.4081/10.4081/ ijas.2010.e20.

Martignani, E., D. Cravero, S. Miretti, P. Accornero, and M. Baratta. 2014. Bovine mammary stem cells: new perspective for dairy science. Vet. Q. 34:52-58. https://doi.org/10.1080/01652176.2014 .894262 .

Mashek, D. G., L. R. Norup, J. B. Andersen, and K. L. Ingvartsen. 2002. Effects of 4-day hyperinsulinemic-euglycemic clamps during early and mid-lactation on milk yield, milk composition, feed intake, and energy balance. Livest. Prod. Sci. 77:241-251. https:// doi.org/10.1016/S0301-6226(02)00037-4

Miller, N., L. Delbecchi, D. Petitclerc, G. F. Wagner, B. G. Talbot, and P. Lacasse. 2006. Effect of stage of lactation and parity on mammary gland cell renewal. J. Dairy Sci. 89:4669-4677. https:// doi.org/10.3168/jds.S0022-0302(06)72517-6.

Olori, V. E., S. Brotherstone, W. G. Hill, and B. J. McGuirk. 1997. Effect of gestation stage on milk yield and composition in Holstein Friesian dairy cattle. Livest. Prod. Sci. 52:167-176. https://doi .org/10.1016/S0301-6226(97)00126-7.

Rastani, R. R., R. R. Grummer, S. J. Bertics, A. Gümen, M. C. Wiltbank, D. G. Mashek, and M. C. Schwab. 2005. Reducing dry period length to simplify feeding transition cows: Milk production, energy balance, and metabolic profiles. J. Dairy Sci. 88:1004-1014. https://doi.org/10.3168/jds.S0022-0302(05)72768-5. 
Rehn, H., B. Berglund, U. Emanuelson, G. Tengroth, and J. Philipsson. 2000. Milk production in Swedish dairy cows managed for calving intervals of 12 and 15 months. Acta Agric. Scand. A Anim. Sci. 50:263-271. https://doi.org/10.1080/090647000750069458.

Reist, M., D. Erdin, D. von Euw, K. Tschuemperlin, H. Leuenberger, C. Delavaud, Y. Chilliard, H. M. Hammon, N. Kuenzi, and J. W. Blum. 2003. Concentrate feeding strategy in lactating dairy cows: Metabolic and endocrine changes with emphasis on leptin. J. Dairy Sci. 86:1690-1706. https://doi.org/10.3168/jds.S0022 -0302(03)73755-2.

SAS Institute. 2011. The SAS System for Windows. Release 9.3. SAS Institute Inc., Cary, NC.

Schlamberger, G., S. Wiedemann, E. Viturro, H. H. D. Meyer, and M. Kaske. 2010. Effects of continuous milking during the dry period or once daily milking in the first 4 weeks of lactation on metabolism and productivity of dairy cows. J. Dairy Sci. 93:2471-2485. https://doi.org/10.3168/jds.2009-2823.

Sorensen, A., and C. H. Knight. 2002. Endocrine profiles of cows undergoing extended lactation in relation to the control of lactation persistency. Domest. Anim. Endocrinol. 23:111-123. https://doi .org/10.1016/S0739-7240(02)00150-9.

Tamminga, S., W. M. Vanstraalen, A. P. J. Subnel, R. G. M. Meijer, A. Steg, C. J. G. Wever, and M. C. Blok. 1994. The Dutch protein evaluation system - The DVE/OEB system. Livest. Prod. Sci. 40:139-155. https://doi.org/10.1016/0301-6226(94)90043-4.

Tannenbaum, G. S., H. J. Guyda, and B. I. Posner. 1983. Insulin-like growth factors: A role in growth hormone negative feedback and body weight regulation via brain. Science 220:77-79. https://doi .org/10.1126/science.6338593.

Thatcher, W. W., C. J. Wilcox, R. J. Collier, D. S. Eley, and H. Herbert Head. 1980. Bovine conceptus - maternal interactions during the pre- and postpartum periods. J. Dairy Sci. 63:1530-1540. https://doi.org/10.3168/jds.S0022-0302(80)83112-2.

Van Amburgh, M. E., D. M. Galton, D. E. Bauman, and R. W. Everett. 1997. Management and economics of extended calving intervals with use of bovine somatotropin. Livest. Prod. Sci. 50:15-28. https://doi.org/10.1016/S0301-6226(97)00069-9.

Van Es, A. J. H. 1975. Feed evaluation for dairy cows. Livest. Prod. Sci. 40:95-107. https://doi.org/10.1016/0301-6226(75)90029-9.

van Hoeij, R. J., J. Dijkstra, R. M. Bruckmaier, J. J. Gross, T. J. Lam, G. J. Remmelink, B. Kemp, and A. T. M. Knegsel. 2017. The effect of dry period length and postpartum level of concentrate on energy balance and plasma metabolites of dairy cows across the dry period and in early lactation. J. Dairy Sci. 100:5863-5879. https://doi.org/10.3168/jds.2016-11703. van Knegsel, A. T., H. van den Brand, J. Dijkstra, W. M. van Straalen, M. J. Heetkamp, S. Tamminga, and B. Kemp. 2007a. Dietary energy source in dairy cows in early lactation: Energy partitioning and milk composition. J. Dairy Sci. 90:1467-1476. https://doi.org/ 10.3168/jds.S0022-0302(07)71632-6.

van Knegsel, A. T. M., G. J. Remmelink, S. Jorjong, V. Fievez, and B. Kemp. 2014. Effect of dry period length and dietary energy source on energy balance, milk yield, and milk composition of dairy cows. J. Dairy Sci. 97:1499-1512. https://doi.org/10.3168/jds.2013-7391.

van Knegsel, A. T. M., H. van den Brand, J. Dijkstra, W. M. van Straalen, R. Jorritsma, S. Tamminga, and B. Kemp. 2007b. Effects of glucogenic vs. lipogenic diets on energy balance, metabolites, and reproduction in primiparous and multiparous dairy cows in early lactation. J. Dairy Sci. 90:3397-3409. https://doi.org/10 $.3168 /$ jds.2006-837.

Vicari, T., J. J. G. C. van den Borne, W. J. J. Gerrits, Y. Zbinden, and J. W. Blum. 2008. Postprandial blood hormone and metabolite concentrations influenced by feeding frequency and feeding level in veal calves. Domest. Anim. Endocrinol. 34:74-88. https://doi.org/ 10.1016/j.domaniend.2006.11.002.

Voelker, J. A., and M. S. Allen. 2003. Pelleted beet pulp substituted for high-moisture corn: 1 . effects on feed intake, chewing behavior and milk production of lactating dairy cows. J. Dairy Sci. 86:35423552. https://doi.org/10.3168/jds.S0022-0302(03)73959-9.

Wathes, D. C., Z. Cheng, M. A. Fenwick, R. Fitzpatrick, and J. Patton. 2011. Influence of energy balance on the somatotrophic axis and matrix metalloproteinase expression in the endometrium of the postpartum dairy cow. Reproduction 141:269-281. https://doi .org/10.1530/REP-10-0177.

Wood, P. D. P. 1967. Algebraic model of the lactation curve in cattle. Nature 216:164-165.

Yart, L., F. Dessauge, L. Finot, S. Barbey, P. G. Marnet, and V. Lollivier. 2012. Ovariectomy improves lactation persistency in dairy cows. J. Dairy Sci. 95:3794-3802. https://doi.org/10.3168/jds.2011 -5195 .

Yart, L., L. Finot, V. Lollivier, and F. Dessauge. 2013. Oestradiol enhances apoptosis in bovine mammary epithelial cells in vitro. J. Dairy Res. 80:113-121. https://doi.org/10.1017/ S0022029912000714

Zom, R. L. G., G. André, and A. M. van Vuuren. 2012. Development of a model for the prediction of feed intake by dairy cows: 1 . Prediction of feed intake. Livest. Sci. 143:43-57. https://doi.org/10 .1016/j.livsci.2011.08.014. 